\begin{tabular}{|c|c|c|}
\hline 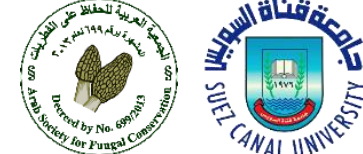 & $\begin{array}{c}\text { Contents lists available at Egyptian Knowledge Bank } \\
\text { Microbial Biosystems } \\
\text { Journal homepage: http://mb.journals.ekb.eg/ }\end{array}$ & $\begin{array}{l}\text { MICROBIAL BIOSYSTEN } \\
\begin{array}{c}\text { INTERNATIONAL SGIENTIFIC JOURN } \\
\text { OF MICROBIAL BIOLOGY }\end{array}\end{array}$ \\
\hline
\end{tabular}

\title{
An annotated bibliography of medical mycology in Iraq: 1962 -2021
}

\author{
Anaam F. Hussain ${ }^{1}$, Huda R. Hashim ${ }^{2}$, Teroj A. Mohamed ${ }^{3 *}$, Ahmed M. Abdel-Azeem ${ }^{*}$ \\ ${ }^{1}$ Biotechnology Department, College of Science, Diyala University, Iraq \\ ${ }^{2}$ Biology Department, College of Science, University of Al-Muthanna, Iraq \\ ${ }^{3}$ Department of Dental Basic Sciences, College of Dentistry, University of Duhok, Iraq. \\ ${ }^{4}$ Botany and Microbiology Department, Faculty of Science, University of Suez Canal, Ismailia 41522, Egypt.

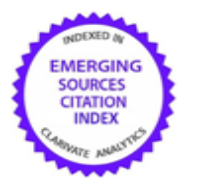

\begin{tabular}{l} 
ARTICLE INFO \\
\hline Article history \\
Received 10 August 2021 \\
Received revised 25 August 2021 \\
Accepted 25 August 2021 \\
Avaliable online 25 August 2021 \\
@ Hussain et al., 2021 \\
Corresponding Editor: \\
A. M. G. Darwish \\
B. A. Balbool
\end{tabular}

Keywords

Antifungal, Aspergillosis

Candida albicans

Dermatophytes, Malassezia

Mucoromycosis, Nanoparticles

\begin{abstract}
One of the gaps in knowledge concerning diversity of fungi in Iraq is checklists and documentation of fungal data. For a country like Iraq no updated checklists of fungi at all or any mycological bibliographic studies up till now. We decided in our newly born Iraqi Mycologists' Network to start a long road for documentation of fungi in Iraq by all available means. By screening of available sources of information (websites, dissertations, theses, journals), it was possible to figure out a range of four hundred and fifty-five articles published since 1962 in Iraq collected from various sources all dealing with some phase of medical mycology. The value of this bibliography to students, researchers and medical mycologists in Iraq and world-wide in this field is self-evident. It should be mentioned here that, although the present study will add some new data to our information concerning medical mycology in Iraq; it must be considered as a provisional one always waiting for continuous supplementation.
\end{abstract}

Published by Arab Society for Fungal Conservation

\section{Introduction}

Information about medical mycology in Iraq are very huge but never been the target of any bibliographic studies before in which this one considered the pioneer. Based on the data collected from previous studies as well as information obtained from web sites, dissertations, published papers, patents, textbooks and compilations of medical mycology in Iraq previously introduced by several investigators it can be deduced that the number of references of medical mycology in Iraq up to the present time is nearly about 455 .

For the ease of reference, studies were sorted out into four main groups since 1960. Studies in the last two decades (2011-2021) are came first by accommodating 320 studies, while the two decades of 1960-1980 came at last by recording only 20 studies. Some references re-edited due to scientifically spelling mistakes and they are few. Some theses were in Arabic, and we were just translated the title. It should be mentioned here that, although the present study will add some new references to our information concerning medical mycology in Iraq, this bibliography can be considered as a provisional one that needs continuous supplementation.

\footnotetext{
* Corresponding author

teroj.mohamed@uod.ac (Teroj A. Mohamed)- ahmed_abdel-azeem@science.suez.edu.eg (Ahmed M. Abdel-Azeem)
} 


\section{Number of Studies}

The number of published and unpublished studies of medical mycology in Iraq in each decade since 1960, as recorded in our extensive survey, shows three distinct phases (Fig. 1): an ascending phase in which progress was very slow in the 1960s to 1990s, a steep phase as different types of studies and molecular identification came into general use in the 1990s to 2010s, and then sudden increase from the 2010s to the present day. The partially higher figures in the last decade reflect continuing exploration and a number of prolific individual medical mycologists.

Data concerning medically important taxa showed that Candida came first be recorded 86 entries out of 455 while genus Aspergillus recorded 24 and genus Penicillium recorded 3 entries only.

This extensive survey which will add new data for the first time to our information concerning medical mycology in Iraq must be considered as a provisional one always waiting for continuous supplementation from all researchers and medical mycologists.

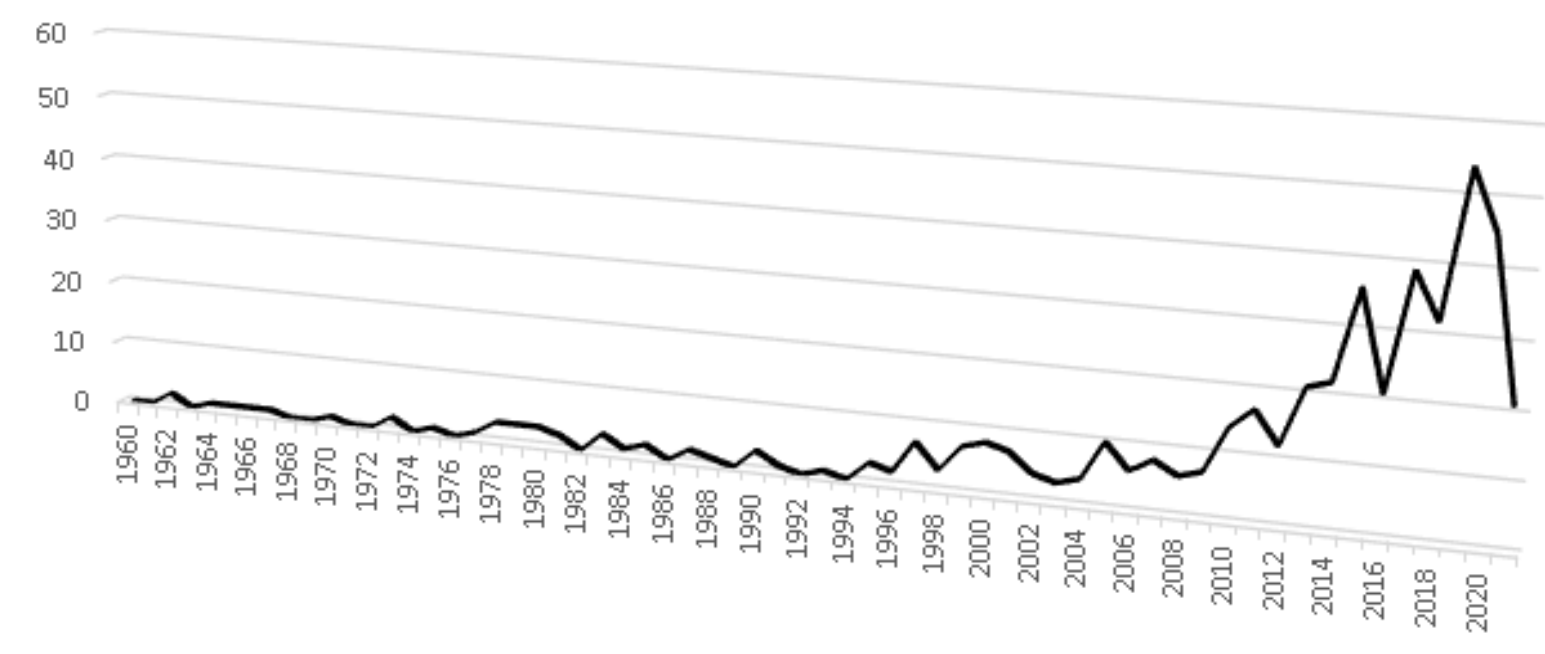

Fig 1. Numbers of newly introduced medical mycology studies in Iraq for each year from 1960 to 2021 based on data from extensive survey during this study.

\section{0-1980}

\section{BIBLIOGRAPHY}

1. Akrawi, F., Rassam, R. H., 1962. Species of fungi which cause ringworm of the scalp in Iraq with a study of the action of griseofulvin on them in vitro. J. Fac. Med. Baghdad.4,1-3.

2. Bank, H., Shibolet, S., Gilat, T., Altmann, G., Heller, H., 1962. Mucormycosis of Head and Neck Structures. Br Med J 1, 766-768.

3. Damluji, S.F., Kotta, E.A., 1964. A Survey of Histoplasmin Sensetivity in Iraq. Bull World Health Org 30, 595-599.

4. Rahim, G.F., 1965. Treatment of tinea capitis: a report on the use of a new antibiotic, griseofulvin. Journal of the Faculty of Medicine, Baghdad 7, 21-26.
5. Rahim, G.F., 1966. A survey of fungi causing tinea capitis in Iraq. $\mathrm{Br} \mathrm{J}$ Derm 78, 213-218. https://doi.org/10.1111/j.1365-2133.1966.tb12207.x

6. Rahim, G.F., 1967. Favus infection in Iraq. Presented at the XIII Congressus Internationalis Dermatologiae, Springer-Verlag, Berlin, Munchen, Germany, pp. 837 839.

7. Randhawa, H.S., 1970. Occurrence of histoplasmosis in Asia. Mycopathologia et Mycologia Applicata 41, 75-89. https://doi.org/10.1007/BF02051485

8. Al-Hamdani, M., Salmo, N.A.M., Hadi, A.W. A. R., 1973. Chromomycosis of the skin: first case report in Iraq. Int $\mathrm{J}$ Dermatol 12, 354-357. https://doi.org/10.1111/j.1365-4362.1973.tb00220.x 
9. Spencer H., Salfelder K., 1973.Tropical Mycotic Diseases. In: Tropical Pathology. Spezielle pathologische Anatomie (Ein Lehr- und Nachschlagewerk), Springer, Berlin, Heidelberg $8,127-212$.

10. Tainsh, A.R., 1975. Primary and secondary mycotoxicosis. International Journal of Environmental Studies 8, 177-181. https://doi.org/10.1080/00207237508709730

11. Ghani, H.M., Yehia, M.M., 1977. Isolation of Cryptococcus neoformans from pigeon droppings in Mosul [Iraq]. Mosul. Ann. Col. Med. Mosul, 8, 111114.

12. Al-Omar L. Sh., 1978. Relationship between Herpes simplex and Candida albicans in female urogenital tract infections (MSc Thesis). Collage of Medicine, University of Baghdad, Iraq.

13. Gummer, A.S., Guirges, S.Y., 1978. Survey of aetiological agents of fungal infections of skin. J . Fac. Med. Baghdad 20, 19-29.

14. Philpot, C.M., 1978. Geographical distribution of the dermatophytes: a review. J Hyg (Lond) 80, 301-313.

15. Abdel-Karim, A.M., Hassan, F. K., Milligy, M., Zahid, N.R., 1979. Soil of animal enclosures as reservoir of fungal infections with special reference to the effect of some disinfectants on the infected soil. The Iraqi J. Vet. Med,.3

16. Al Dubooni, H.M., 1979. Epdimio-Clinical studies of Cryptococcus neoformans in Mosul and vicinity (MSc Thesis). College of Medicine, University of Mosul, Iraq.

17. AL-Zubaidi, K.A., 1979. Histopathology and serology of Candida albicans infection (MSc Thesis). University of Baghdad, Iraq.

18. Al-Doory, Y., 1980. Laboratory medical mycology. Philadelphia, Lea and Febiger, 410 pp.

19. Al-Tikriti, S.K., Al-Salihi, M., Gaillard, G.E., 1980. Pollen and mold survey of Baghdad, Iraq. Annals of Allergy 45, 97-99.

20. Yehia, M.M., 1980. Studies on dermatophytes in Mosul and vicinity (MSc Thesis). College of Medicine, University of Mosul, Iraq.

\section{1-2000}

21. AL-Bakri, A.M., 1981. Mycological study of vulvovaginal candidiasis In Mosul (MSc Thesis). College of Medicine, University of Mosul, Iraq.

22. Guirges, S.Y., 1981. Viability of Trichophyton schoenleinii in epilated hairs. Sabouraudia: Journal of Medical and Veterinary Mycology 19, 155-156. https://doi.org/10.1080/00362178185380231
23. Abdullah, B.A., 1983. Atopic allergy to some prevalent fungi in Mosul: Correlation between total serum IGE label, skin test reactivity and percentage of eosinophils (MSc Thesis). College of Medicine, University of Mosul, Iraq.

24. Gabal, M.A., Hassan, F.K., Siad, A.A., Karim, K.A., 1983. Study of equine histoplasmosis farciminosi and characterization of Histoplasma farciminosum. Sabouraudia: Journal of Medical and Veterinary Mycology 21, 121-127. https://doi.org/10.1080/00362178385380191

25. Hay, R.J., Campbell, C.K., Marshall, W.M., Rees, B.I., Pincott, J., 1983. Disseminated zygomycosis (mucormycosis) caused by Saksenaea vasiformis. Journal of Infection 7, 162-165. https://doi.org/10.1016/S0163-4453(83)90695-3

26. Macdonald, E., Smith, E.B., 1984. The geography of the dermatophytes. Dermatologic Clinics 2, 85-91. https://doi.org/10.1016/S0733-8635(18)30992-6

27. Sharquie, K., Al-Zubaidi, K., 1985. Microsporum canis in Iraq. Saudi Medical Journal 6, 248-250.

28. Khider, M., 1985. Candida species and other Microorganisms isolated from female Genital tract infection (MSc Thesis). College of Medicine, University of Baghdad.

29. Al-Deen, I. H. S., Twaij, H.A.A., Al-Badr, A.A., Istarabadi, T.A.W., 1987. Toxicologic and histopathologic studies of Pleurotus ostreatus mushroom in mice. Journal of Ethnopharmacology 21, 297-305. https://doi.org/10.1016/03788741(87)90105-X

30. Guirges, S.Y., Al-Waili, N.S., 1987. Blastocystis hominis: evidence for human pathogenicity and effectiveness of metronidazole therapy. Clin Exp Pharmacol Physiol 14, 333-335. https://doi.org/10.1111/j.1440-1681.1987.tb00979.x

31. Mawlud, A. O., 1988. A survey of superficial fungal infections of skin (Diploma Thesis). College of Medicine, University of Baghdad, Iraq.

32. Ali, T.M., 1990. Tinea capitis: Clinical and mycological study (MSc Thesis). College of Medicine, University of Baghdad, Iraq.

33. Yazachi, M., Al Bassam, Th. A., 1990. Dermatomycosis in Iraq. Journal of the Faculty of Medicine-Baghdad. 32, 431-47.

34. Yehia, M.M., al-Habib, H.M., Shehab, N.M., 1990. Otomycosis: a common problem in north Iraq. $\mathrm{J}$ Laryngol Otol 104, 387-389. https://doi.org/10.1017/s0022215100158529

35. Al-Rubaie, M., 1991. Clinico-epidemiological study of pityriasis versicolor in Baghdad (MSc Thesis). College of Medicine, University of Al-Mustansiriya, Iraq. 
36. Mehdi, L.K., 1993. Candida species as intestinal flora, their overgrowth and absence (MSc Thesis). College of Medicine, University of Baghdad, Iraq.

37. Abass, N.K., 1995. Mycological and bacteriological study of Head and calp lesions (MSc Thesis). College of Medicine, Baghdad University.

38. Abdulkareem, S., 1995. Study of the effect of extracts of the Medicago sativa roots on some pathogenic fungi in vitro and in vivo (MSc Thesis). College of Veterinary Medicine, Baghdad University, Iraq.

39. Abdullah, S.K., Hassan, D.A., 1995. Isolation of dermatophytes and other keratinophilic fungi from surface sediments of the Shatt Al-Arab River and its creeks at Basrah, Iraq. Mycoses 38, 163-166. https://doi.org/10.1111/j.1439-0507.1995.tb00042.x

40. Al-Janabi, A.A.S., 1996. Effect of some plant extracts on some dermatophytes growth which cause skin disease (MSc Thesis). College of Science. Al Mustansiriya University, Iraq.

41. Taj-Aldeen, S.J., Alkenany, K.I., 1996. Separation and partial purification of beta-glucosidase and two endoglucanases in Aspergillus niveus. Microbiologia $12,91-98$.

42. AL-Ani, S.A., 1997. Isolation and identification of opportunistic fungi in Basrah hospitals with a study on effect of sojyuyjuyme disinfectant in Basrah hospitals (MSc Thesis). College of Science, Basrah University, Iraq.

43. Al-Duboon, A. H., 1997. A study on superficial cutaneous mycoses in Basrah (Iraq) ( $\mathrm{PhD}$ Thesis). College of science, University of Basrah, Iraq.

44. Al-Hamadani, A.H.A., 1997. Enzymic activity, purification of keratinizes and proteinase and their roles in the pathogenicity and immunogenicity of clinical isolate and yeasts ( $\mathrm{PhD}$ Thesis). College of Education, University of Bagdad, Iraq.

45. Al-Tikrity, A.T., 1997. Evaluation of antifuugal activity of some plants extracts against dermal fungi (MSc Thesis). College of Medicine, Tikrit University, Iraq.

46. Mousa, H.A., 1997. Aerobic, anaerobic and fungal burn wound infections. J Hosp Infect 37, 317-323. https://doi.org/10.1016/s0195-6701(97)90148-1

47. Muhsin, T.M., Aubaid, A.H., Al-Duboon, A.H., 1997. Extracellular enzyme activities of dermatophytes and yeast isolates on solid media. Mycoses 40, 465-469. https://doi.org/10.1111/j.1439-0507.1997.tb00186.x

48. Zilinskas, R.A., 1997. Iraq's biological weapons. The past as future? JAMA 278, 418-424.

49. Al-Duboon, A.H., 1998.. Antifungal susceptibility of fungi causing Otomycosis in Basrah. Med. J. Basrah $16,87-98$.
50. Aubaid, A.H., Muhsin, T.M., 1998. Partial purification and kinetic studies of exocellular proteinase from Trichophyton mentagrophytes var. erinacei. Mycoses 41, 163-168. https://doi.org/10.1111/j.14390507.1998.tb00318.x

51. Mahdi, N.K., Al Hamdani, M.M., 1998. Sexually transmitted diseases among women with habitual abortion. EMHJ - Eastern Mediterranean Health Journal, 4 (2), 343-349.

52. Al-Duboon, A.H., Muhsin, T.M., al-Rubaiy, K.K., 1999. Tinea capitis in Basrah, Iraq. Mycoses 42, 331333. https://doi.org/10.1046/j.14390507.1999.00462.x

53. Al Gailani, D.M., Karhoot, J.M., Shareef, F.M., 1999. The activity of various antifungal drugs against new Candida isolates among Iraqi patients. Journal of Faculty of Medicine, Baghdad University 41, 250-255.

54. AL-Janab, A.E., 1999. A new method for rapid diagnostic of Candida albicans in blood (MSc Thesis). Collage of Medicine, Anbar University, Iraq.

55. Aubaid, A. H., A. Z., Risan, Naem, A. K., 1999. Detection of sugars and amino acids in antigens of Trichophyton mentagrophytes var. erinacei. Mycoses 42, 249-253. https://doi.org/10.1046/j.14390507.1999.00459.x

56. Mousa, H.A., Al-Bader, S.M., Hassan, D.A., 1999. Correlation between fungi isolated from burn wounds and burn care units. Burns 25, 145-147. https://doi.org/10.1016/s0305-4179(98)00148-x

57. Mousa, H.A., 1999. Fungal infection of burn wounds in patients with open and occlusive treatment methods. East Mediterr Health J 5, 333-336.

58. Muhsin, Al-Rubaiy, Al-Duboon, 1999. Characteristics of dermatophytoses in Basrah, Iraq. Mycoses 42, 335338.

https://doi.org/10.1046/j.14390507.1999.00463.x

59. Al-Ani, A.A.M., 2000. Fungi and associated bacteria isolated from infected ear in AL-Yarmouk teaching hospital (PhD Thesis). Collage of Medicin, University of Al-Mustansiriya, Iraq.

60. Al Duboon, A., Al Rubaie, K.K., Muhsin, T.M., 2000. A study of Pitryasis versicolor in Basrah (Iraq). Med. J. Basrah 19, 31-34.

61. Al-Hadithi H.S., 2000. Prevalence of bacterial vaginosis and other vaginal infection among different groups of Iraqi women, correlated with their Estrogen level and vaginal $\mathrm{pH}$ (MSc Thesis). Collage of Medicine. University of Baghdad, Iraq.

62. Al-Hashime S. A., 2000. The role of Candida albicans in vulvovaginosis (MSc Thesis). Collage of Science, University of Al-Mustansiriya, Iraq.

63. Al-Khaphagi, B.R.A., 2000. Effect of Withania somnifera, Salvia officinalis and Salix acmphylla 
extracts on the growth of some dermatophytes (MSc Thesis). College of Science, Al Mustansiriya University, Iraq.

64. Fathi, H.I., Al Samarai, A.G.M., 2000a. Prevalence of tinea capitis among schoolchildren in Iraq. EMHJ Eastern Mediterranean Health Journal, 6 (1), 128-137.

65. Fathi, H.I., al-Samarai, A.M., 2000b. Tinea capitis in Iraq: laboratory results. East Med Health J 6, 138-148.

66. Mahmoodi, W.R., 2000. Survey of dermatophytes infections in Babylon governorate (MSc Thesis). College of Science, University of Babil, Iraq.

\section{1-2010}

67. Al Enzy, M.A.M., 2001. Study of the damaged between Allium sativum L. extract and extracts of other medicinal plants as antifungals (MSc Thesis). College of Science, University of Mosul, Iraq.

68. AL-Kinany, F.G., 2001. Dermal fungi sensitivity and opportunistic towards some plant extracts prepared in laboratory. Collage of Education. University of Basrah, Iraq.

69. Al-Maliky, K.R.S., 2001. Otomycosis in Missan Province the etiological agents and effectiveness of five available antifungal agent (MSc Thesis). College of Medical and Health Technology. Baghdad University, Iraq.

70. AL-Zuhairi, O.K.R., 2001. Microorganisms isolated from vagina of pregnant women in Baquba city (Diploma Thesis). University of Baghdad, Iraq.

71. Mousa, H.A., al-Bader, S.M., 2001. Yeast infection of burns. Mycoses 44, 147-149. https://doi.org/10.1046/j.1439-0507.2001.00627.x

72. Muhsin, T.M., Aubaid, A.H., 2001. Partial purification and some biochemical characteristics of exocellular keratinase from Trichophyton mentagrophytes var. erinacei. Mycopathologia 150, 121-125. https://doi.org/10.1023/A:1010900403141

73. Muhsin, T.M., Salih, T.H., 2001. Exocellular enzyme activity of dermatophytes and other fungi isolated from ruminants in Southern Iraq. Mycopathologia 150, 4952. https://doi.org/10.1023/a:1010854322655

74. Abdullah, S.K., Al-Hamdani, F.M., Naama, M.S., 2002. Incidence and etiologic study of onychomycosis in Basrah, Iraq. Iraqi Journal of Biology 2, 464-468.

75. Hammad, E.F., Al-Janabi, A.A., Mohamed, S.A., 2002. Fungi that grow on formalin-fixed cadavers. Saudi Med J 23, 871-872.

76. Kassab, N.H., 2002. Antifungal effect of some agents on Candida albicans growth on acrylic resin denture base surface (in vitro study) (MSc Thesis). Collage of Dentistry, University of Mousel, Iraq.

77. Kezeer, E. G., 2002. Incidence of dermatophytosis among children. J. Al-Tachaniya, Baghdad, 3, 40-44.
78. Ahmed, W.I., 2003. Microbiological and immunological aspects of candidiasis in human $(\mathrm{PhD}$ Thesis). Collage of Veterinary Medicine, University of Baghdad, Iraq.

79. Hasso, S.A., 2003. Non-fatal aflatoxicosis in Arabian horses in Iraq. Vet Rec 152, 657-658. https://doi.org/10.1136/vr.152.21.657

80. Jassim, J.S., 2003. Effect of Haloxylon articulatum extract on some experimental bacterial and fungal skin infection in dogs (MSc Thesis). College of Veterinary Medicine, Baghdad University, Iraq.

81. Ahmed, W., 2004. Isolation and identification of Malassezia species in Pityriasis versicolor in Baghdad (A thesis of requirement for the degree of fellowship of Iraqi board for medical specialization). Iraqi Board for Medical Specialization, Iraq.

82. AL-Byatti, E.N., 2004. Bacterial interference in the virulence factors of the yeast Candida causing vulvovaginal candidiasis ( $\mathrm{PhD}$ Thesis). College of Science, Al-Mustansiriya University, Iraq.

83. AL-Hachami, Sh.N.M., 2004. Isolation and Identification of Candida albicans from vaginal and study of virulence factors and sensitivity to antifungal agents (MSc Thesis). College of Education (Ibn ALHaitham), University of Baghdad, Iraq.

84. Majeed, H.A., 2004. Identification and immunological study of Candida spp. causing vaginitis (MSc Thesis). College of Science for Women, University of Baghdad, Iraq.

85. Abo-Mujamdad, N.M.J.A., 2005. evaluation activity of some plant extracts against some fungi causes superficial mycoses (MSc Thesis). College of Science, University of Basrah, Iraq.

86. AL-Ameri, N.O., 2005. A study of taxonomy and epidemiology of pulmonary mycotic infection in ALQadisyia province (PhD Thesis). Collage of Education. AL-Qadisyia University, Iraq.

87. Al Doorky, S.Y., 2005. Isolation and identification of fungi associated with immunocompromised patients and study of the immune response against Candida albicans ( $\mathrm{PhD}$ Thesis). College of Science, $\mathrm{Al}$ Mustansirya Universiry, Iraq.

88. Al-Hamadani, A.H.A., W.Al-Bideri, A., H.Saleh, T., 2005. Effect of extracted antigens from some pathogenic fungi on the mice skin. Al-Qadisiyah Medical Journal 1, 1-6.

89. Al-Janabi, A.A., Hussien, A., Al-Khafaji, K.A.H., 2005. A survey of Dermatophytoses in Hilla. Medical Journal of Babylon 2, 120-122.

90. Al-Khafaji, K.A.H., 2005. Isolation of Candida species from normal individuals in Hilla-Iraq. Medical Journal of Babylon 2, 259-262. 
91. Al-Khazaali, M.T.A., 2005. Happens of dermal fungi infections between populations in Baquba city (MSc Thesis). College of Education, University of Diyala, Iraq.

92. Hamad, N.S., Salem, Z., 2005. Evaluation efficiency of Thymus vulgaris L. plant extract on some fungi isolated from mouth and nose of patient children in maternity and children hospital In Babylon province. Journal of Kerbala University 1, 93-113.

93. Janabi, A.A.H.S.A.-, Khafaji, K.A.A.-, 2005. A survey of dermatophytoses in Hilla. Medical Journal of Babylon 2, 120-122.

94. Jibouri, S.W.A., Hassan, F.K., 2005. The effect of Some antiseptics on selected nosocomial fungi isolated from Al- Yarmouk Hospital. Iraqi Journal of Community Medicine 18, 140-146.

95. Al-Janabi, S.G., 2006. Dermatophytes infection in Baghdad: Clinical and laboratory study (PhD Thesis). College of Medicine, Ibn Al-Haitham University, Iraq.

96. Al-Obadi, W.I., Al- Abidi, N.A., 2006. Candida albicans infection among Iraqi women: some epidemiological variables. Iraqi Journal of Medical Sciences 5, 13-16.

97. Jabur, W.L., Aljebory, H.M., 2006. Post dialysis Rhino cerebral Mucormycosis. Saudi Journal of Kidney Diseases and Transplantation 17, 62-63.

98. Janabi, A.A.H.S.A., 2006. Diagnoses of Trichophyton simii in Iraq. Al-Mustansiriyah Journal of Science 17, 11-14.

99. Janabi, A.A.-H.S.A.-, 2006. Relationship between blood glucose level and skin fungi infection. Journal of Karbala University 4, 186-188.

100. Shamoon, G., Rasheed, B., Hamad, M., 2006. Isolation and identification of pathogenic fungi from the infected eye of sheep and cattle. Iraqi Journal of Veterinary Sciences 20, 213-218. https://doi.org/10.33899/ijvs.2006.45799

101. Ahmed, L.T., Kadhim, H.M., 2007. The effect of some plant extracts on pathogenic fungi that cause human and animal infections. Diala J. 7, 1-10.

102. AL-Hamdani, A.H., A.AL-Shammary, M., Jabbar, R.S., 2007a. Epidemiologic study of opportunistic fungi contaminating soil of schools, mosques and hotels in Diwaniya City - Iraq. Al-Qadisiyah Medical Journal 3, 195-208.

103. AL-Hamdani, A.H., In, J.K. ml hi, Kareem, A.A., 2007b. Effects of enaminothiones compounds on the dermatophyes and yeast isolates in vitro. Al-Qadisiyah Medical Journal 3, 209-215.

104. AL-Janabi, A.A., 2007. Explanation of theophylline site of action in cells of skin pathogenic fungi by inhibition cascade hypothesis. Karbala J Med 1, 248251.
105. Barrak, H.A., 2007. Hard palate perforation due to mucormycosis: report of four cases. J Laryngol Otol 121 , 1099-1102. https://doi.org/10.1017/S0022215107006354

106. Farhan, A.-H.A.F.J., 2007. Dermatophytosis in sheep of Al-Safat show in Basrah, Iraq. Basrah Journal of Veterinary Research. 6, 54-62.

107. Firas Elias, D., 2007. Superficial fungal infection of the skin in patients with rheumatoid arthritis after methotrexate therapy. PMJ-Iraqi Postgraduate Medical Journal 6, 352-355.

108. Faza'a, S. A., Natheer, Q., Emad, N., 2007. Skin infections in patients with diabetes mellitus: a caseseries study. Al-Qadisiyah Medical Journal 3, 170 177.

109. AL-Janabi, A.A.H., 2008. Epidemic of dermatophytes infection: Review article (Published in Arabic). Journal of Karbala 6, 239-243.

110. AL-Alwani, H.R.S., 2008. Bacterial vaginosis and Candida albicans vaginitis among women in Ramadi City. Al- Anbar Medical Journal 6, 13-18.

111. Hafidh, R.R., Abdul Amir, A.S., 2008. Cladosporium spp. as a causative agent of white superficial onychomycosis. EMHJ - Eastern Mediterranean Health Journal, 14, 231-233.

112. Hasan, A.R.S., Al-Duliami, A.A., Al-Azawi, N.S., 2008. The Rate of cutaneous candidiasis in patients with skin mycoses in Baquba/Diyala Province-Iraq. Iraqi Journal of Community Medicine 21, 242-245.

113. Kasim, S.E., Salih, Y.I., 2008. Allergic bronchopulmonary aspergillosis with tuberculosis like lesion: A case report. The Medical Journal of Tikrit University 2, 143-144.

114. Malih, H.R., 2008. Inhibitory effect of some plant extracts on growth of some bacteria and fungi pathogens. Thi-Qar Medical Journal 2, 68-77.

115. Al-Ammari, A.M., 2009. Relation of Malassezia species with some skin diseases (MSc Thesis). College of Science, University of Baghdad, Iraq.

116. Al-Janabi, A.S., 2009. In vitro and in vivo therapeutic activity of ibuprofen against dermatophytes. Saudi Med J 30, 624-628.

117. Al-kaissi, E., Al-Magdi, K.J., 2009. Pathogenicity of Blastocystis hominis in relation to entropathogens in gastroenteritis cases in Baghdad. Eur. J. SciRes 25, 606-613.

118. Al Samarai, A.G.M., 2009. Prevalence of skin diseases in Iraq: A community based study. Int J Dermatol 48, 734-739. https://doi.org/10.1111/j.13654632.2009.03812.x

119. Dheeb, B.I., 2009. Study the effecy of Ricinus communis and Syzygium aromaticum on some protease 
producing fungi that cause otitis external (MSc Thesis). College of Science, Tikrit University, Iraq.

120. Hasan, A.R.Sh., Al Dulaimi, A.A., Abdul-Hasan, M.T., 2009. A clinical and laboratory study of dermatophytoses in Diyala province. Diyala province J. Appl. Res. 5, 10-15.

121. Hasan, A.S., Alduliami, A.A., Al-Kialy, K.M., 2009. Clinical and fungal study of Pityriasis versicolor infection among patients with skin mycoses in Baquba. Iraqi Journal of Community Medicine 22, 30-33.

122. Abdul-Hussein, A.A., 2010. Clinical and pigmentary variation of Pityriasis versicolor in Al-Muthana Government's Patients. Medical Journal of Babylon 7, 383-388.

123. Abid-Ali, W.J., 2010. Effect of some antifungals and medicinal herbal against dermatophytes isolated from tinea capitis in Al-Diwaniya governorate (MSc Thesis). Collage of Science, University of Baghdad, Iraq.

124. Al-Duboon, A.-H., 2010. Candiduria and urinary candidiasis in Basrah, Iraq. Journal of Basrah Researches (Sciences) 36, 9-20.

125. AL- Hilaly, H., Ismaeel Nassir Al-Rubaye, N., H. AlHamadani, A., 2010. Detection of causative agents, antifungal susceptibility profile and cross-resistance of Candida albicans isolated from oral and vaginal candidiasis. Al-Qadisiah Medical Journal 6, 197-209.

126. AL-Janabi, A.A.H.S., 2010. Synergistic Properties of Methylxanthine with Cadmium and Mercury on Dermatophytes. J Glob Infect Dis 2, 101-104. https://doi.org/10.4103/0974-777X.62878

127. Al-Musoui, H.R.H., 2010. Isolating and identifying fungi in Al- Diwanya River and the possibility of using them as indicators of ecological pollution (MSc Thesis). College of Education, Al-Qadisiya University, Iraq.

128. Al-Barzenji, H.A.A.-, Taher, Z., Jubouri, R.A.-, 2010. The effect of static magnetic field on some oral microorganisms (an in vitro study). The Medical Journal of Tikrit University 2, 34-39.

129. Hussain, A.F., 2010. The chemical composition of Salix acmophylla L. and the effect of ethanolic extract in Candida albicans. Diyala Journal for pure sciences $6,117-125$.

130. Hussain, H.T., 2010. Isolation of Blastomyces dermatitidis histopathologically and immunologically in Baghdad (MSc Thesis). College of Medicine, AlNahrain University, Iraq.

131. Hussain, M.H., 2010. Survey on Dermatophytosis in $\begin{array}{llll}\text { Iraqi } & \text { camels. }\end{array}$ https://doi.org/10.29079/vol9iss3art124

132. Jassim, A.N., Majeed, H.A., Habib, K.A., 2010. Effect of Some predisposing factors on vulvovaginal candidiasis. Baghdad Journal for Sciences 7, 10871090.

133. Khammas, A.H., Abbas, A.K., Ilabi, S., Al-Najjar, A.R., 2010. Isolation and identification of fungi associated with otomycosis. Iraqi Journal of Community Medicine 23, 186-189.

134. Shafiq, S.A., Al- Joofy, A.K., 2010. Histopathological and enzymatic study on the effect of Aspergillus fumigatus in mice. Journal of the Faculty of Medicine Baghdad 52, 480-483.

135. Tamoze, S.H., 2010. Effect of Cminum cyminum and Nigilla sativa extract on fungi that cause of Otitis Media. Al-Qadisiyah Journal of pure science 15, 9-21.

\section{1-2021}

136. Abdul Hussein, A., Al-Janabi, S., 2011. Investigation of anti-dermatophytic effects of non-steroidal antiinflammatory drugs on Trichophyton mentagrophytes and Epidermophyton floccosum. Iran J Pharm Res 10, 547-552.

137. AL-Maliki, S, R., AL-Ani, Z. I., 2011. Antifungal resistance of Candida species isolated from Iraqi women infected with vulvovaginal candidiasis. AlQadisiah Medical Journal 7, 117-127.

138. AL-Janabi, A., 2011. Consumption of Non-steroidal anti-inflammatory drugs by dermatophytes as alternative carbon source. Pharmacologia 2, 197-200. https://doi.org/10.5567/pharmacologia.2011.197.200

139. Al-Janabi, A.A.H.S., 2011a. Determination of antidermatophytic effects of non-steroidal antiinflammatory drugs on Trichophyton mentagrophytes and Epidermophyton floccosum. Mycoses 54, e443448. https://doi.org/10.1111/j.14390507.2010.01945.x

140. Al-Janabi, A.A.H.S., 2011b. Toxic effect of heavy metals on dermatophytes: Toxic effect of heavy metals on dermatophytes. Mycoses 54, 345-349. https://doi.org/10.1111/j.1439-0507.2010.01876.x

141. Al-Kayalli, K.K., 2011. The rate of superficial fungal infections among patients with different skin diseases in Diyala Iraq. Iraqi Journal of Community Medicine 24, 264-266.

142. Al-Rekabi, H.Y., 2011. Study the effect of some algae extracts against activity of some fungi. University of Thi-Qar Journal 6, 1-8.

143. Mohammed, S. J., Faraj, M. K., 2011. A Survey of dermatophytes isolated from cows and sheep in Iraq. The Iraqi Journal of Veterinary Medicine 35, 40-45.

144. Hafidh, R.R., Abdulamir, A.S., Vern, L.S., Abu Bakar, F., Abas, F., Jahanshiri, F., Sekawi, Z., 2011. Inhibition of growth of highly resistant bacterial and fungal pathogens by a natural product. Open Microbiol J 5, 
96-106.

https://doi.org/10.2174/1874285801105010096

145. Hussein, H.M., Teameoz, S. H., Menher, L. F., 2011. Effect study of garlic honey extract fungus isolated from Musca domestica and some patients. AlQadisiyah Journal of Pure Science 16, 41-50.

146. Ismaeil, A.S., Taha, M.I., Sarmamy, A.O., 2011. Antifungal activity of pomegranate and oak galls extracts against Penicillium spp. and Aspergillus niger. Rafidain Journal of Science 22, 1-10. https://doi.org/10.33899/rjs.2011.31130

147. Jasim, R.M., Abd AL-khaliq, I.M., 2011. Inhibitory effect of aqueous Salvia officinalis's leaves in the growth of Candida albicans from infected women with vaginal candidiasis. Al-Kindy College Medical Journal 7, 47-49.

148. Khlifa, K.A., Al-Kaseer, A., Al-Diwan, J.K., Al-Lami, F.H.,, 2011. Prevalence of tinea capitis among Primary School Children in Baghdad Governorate, Iraq. Iraqi Journal of Community Medicine 24, 9-11.

149. Mohammad, I.O., 2011. Evaluation the Efficiency of Thymus vulgaris and Mantha pipertia plant extract and antibiotic against of Candida spp isolated form human in Diyala province (MSc Thesis). College of Education for Pure Science, University of Diyala, Iraq.

150. Nkaelan, A.M., 2011. Medical Mycology. Dar Djlah Publishing \& Distribution, Jordan, Pp 400.

151. Szema, A.M., Salihi, W., Savary, K., Chen, J.J., 2011. Respiratory symptoms necessitating spirometry among soldiers with Iraq/Afghanistan war lung injury. Journal of Occupational \& Environmental Medicine 53, 961965. https://doi.org/10.1097/JOM.0b013e31822c9f05

152. Yehia, M.M., Abdulla, Z.A., 2011. Isolation of Histoplasma capsulatum and Blastomyces dermatitidis from Iraqi Patients with Lower Respiratory Tract Infections. J IMA 43, 68-73. https://doi.org/10.5915/43-2-5929

153. Abbas, A.K., Mohammed, Z.A., Mahmoud, I.S., 2012. Superficial fungal infections. Mustansiriya Medical Journal 11, 75-77.

154. Abdulkadhim, M.H., 2012. Isolation of Candida sp. from sub-clinical mastitic she-camels. Kufa Journal for Veterinary Medical Sciences 3, 1-9.

155. Alghnam, H.M., AL-Dabbagh, N.Y., 2012. Diagnostic efficiency of a new Candida albicans rapid test device and the importance of some risk factors of vulvovaginal Candidiasis in Mosul city. Rafidain Journal of Science 23, 13-22. https://doi.org/10.33899/rjs.2012.59649

156. Al-Hakeim, H., Muhsin, A.H., Hussein, M.A., 2012. Evaluation of the biological activity of a new hydrocortisone derivative against some pathogenic skin fungi. Clinical Medicine Insights Dermatology 5, 1-7. https://doi.org/10.4137/CMD.S9072
157. Al-Khalidi, A. A., 2012. Isolation of main fungi associated with respiratory infections in human and bovine with study the effect of $\beta$-glucan and fungal antigen against pathogenesis of mucor spp in mice (MSc Thesis). College of Veterinary Medicine, Baghdad University, Iraq.

158. Alsaadoon, A., Abu-Mejdad, N., Al-Mayah, A., 2012. A new record of Trichophyton gourvilii Cantanei, the etiological agent of tinea pedis in Iraq. Basrah Journal of Science 30, 45-52.

159. Humada, Th.A., Saadoon, I.H., Salih, M.A., Khalaf, H.Y., Salih, N.I., 2012. The effect of garlic extract and volatile oil on growth of Trichophyton mentagrophytes. Tikrit Journal of Pharmaceutical Sciences 2, 18152716.

160. Karhoot, J., Al-Nuaimi, A., Warkaa, F., 2012. Isolation and Identification of Malassezia species with pityriasis versicolor patients. The Iraqi Post Graduate Medical Journal 11, 24-28.

161. Mohammad, E.J., 2012. Catheter associated fungal urinary tract infection. Iraqi Postgraduate Medical Journal 11, 326-329.

162. Mohammed, N.A., 2012. Detection of Candida spp. and other pathogens responsible for vulvovaginitis in women with contraceptive methods (MSc Thesis). College of Science, University of Baghdad, Iraq.

163. Muhsin, T., Adlan, M., 2012. Seasonal distribution pattern of outdoor airborne fungi in Basrah city, southern Iraq. J Basrah Res (Sciences) 38, 90-98.

164. Shareef, F.M., 2012. Medical Fungi, Ist. ed. AlThakera Publishing \& Distributors, Irbil, Iraq, Pp 608.

165. Abbas, F.N., 2013. Antifungal activities of alcoholic and aqueous extracts of Punica granatum against some non-dermatophytic fungi. Thi-Qar Medical Journal 7, 101-119.

166. Al- Jeboori, K.H., Al- Harreery, S.A.H., 2013. Study on mycotic dissemination and pathological findings associated with experimental Candida albicans infection in balb/c mice. Global Journal of Bio-Science and Biotechnology 2, 534-538.

167. Al-Ani, W.A., 2013. Microbial contamination of cellular mobile devices used by medical staff and healthcare workers (HCWs) in Al-Yarmouk teaching hospital, Baghdad, Iraq. Mustansiriya Medical Journal $12,22-28$.

168. Al-Azawi, T.H.M., 2013. Epidemiological and molecular study of some keratinophilic Fungi in swimming pools (MSc Thesis). College of Science for Women. Baghdad University, Iraq.

169. Al-Kattan, S.A.A.-K., Burhan, D.T., 2013. Biofilm formation on intrauterine device and associated infections. Iraqi Postgraduate Medical Journal 12, 562 567. 
170. Alkhafaji, K.A., Maamori, Z.K., 2013. Most important medical fungi and their pathogenicity, 1st ed. Dar AlBashaer Al-Islamiya for Printing, Publishing \& Distribution Sarl, Beirut, Lebanon, Pp: 285.

171. Al-Rejaboo, M.A., Al-Obaidy, O.M., 2013. Inhibitory effect of alcoholic extract of Sage leaves on the growth of pathogenic fungi causing external ear and skin infections. Journal of Life Sciences 7, 468-474.

172. Al-Sabhany, H.S., 2013. The effect of the Panax ginseng plant extract some molds and yeasts isolated from different infection samples of some patients in city of Baghdad (MSc Thesis). College of Science, University of Tikrit, Iraq.

173. AlSaidy, H.A.M., 2013. evaluation Efficiency of garlic and colocynth as crude extraction and some antifungal effects on fungus Candida albicans, which isolated from patients of Diyala province towns. Iraq. International Journal of Agricultural Science and Research 3, 2250-2257.

174. AL-Tameemi, H.A.A.N., Khalaf, J.M., 2013. Isolation and identification of fungi from wounds and burns of human and farm animals. The Iraqi Journal of Veterinary Medicine (IJVM) 37, 251-256.

175. Daoowd, W.S., 2013. In vitro antifungal activity of extracts of Anastatica hierochuntica. Kufa Journal for Veterinary Medical Sciences 4, 142-148.

176. Dekhil, K.R., Sayhoud, A.S., Mahdi, S., 2013. Otomycosis associated with active chronic otitis media. Al-Qadisiyah Medical Journal 9, 46-51.

177. Dheeb, B.I., 2013. Study on the pathogenicity, cytotoxicity and virulence factors of some clinical of Aspergillus fumigatus isolates and the use of RAPD markers to distinguish them (MSc Thesis). College of Science, Tikrit University, Iraq.

178. Gharib, A.A., Youssf, A. E., Omnia, A. E., Taha, M., 2013. Antimicrobial activity of propolis against some bacteria and fungi. Zagazig Veterinary Journal 41, 8197. https://doi.org/10.21608/zvjz.2013.94459

179. Hasan, S. M., 2013. The Prevalence of Cutaneous Trichophyton spp in patients with Skin mycosis in Babylon Province. Al-Kufa University Journal for Biology 5, 192-198.

180. Imran, Z. K., Al-Ghalibi, H., 2013. Genotypic identification of Candida spp. isolated from onychocandidiasis patients by phenotypic methods, PCR and RAPD-PCR. Current Research in Medicine 5, 1-7. https://doi.org/10.3844/amjsp.2014.1.7

181. Kaab, H.T., 2013. Genotyping of Candida albicans isolated from broilers by $25 \mathrm{~S}$ rDNA Analysis. Kufa Journal for Veterinary Medical Sciences 4, 105-110.

182. Kasim, Z.S., Yehia, M.M., 2013. Unusual yeasts isolated from immunocompromised patients. Iraqi Journal of Pharmacy 13, 13-21.
183. Sabeeh, S., Al-Attraqhchi, A.A.F., Al-Aswad, E., 2013. PCR in comparison with culture methods for the diagnosis of Candida albicans responsible for Candidemia in leukemic patients. Diyala Journal of Medicine 5, 29-35.

184. Salman, Z.A., 2013. Identification of Trichophyton rubrum isolates by using traditional methods and RAPD- PCR (MSc Thesis). College of Science, University of Baghdad, Iraq.

185. Shekha, Y.A., Ismael, H. M., Ahmed, A. A., 2013. Bacteriological and mycological assessment for water quality of Duhok reservoir, Iraq. Jordan Journal of Biological Sciences 6, 308-315. https://doi.org/10.12816/0001630

186. Abood, M.S., 2014. Immunological and molecular study of Candida spp. causing vulvovaginal candidiasis and the role of lactic acid bacteria as probiotic in vivo and in vitro ( $\mathrm{PhD}$ Thesis). College of Science, University of Baghdad, Iraq.

187. Ajah, H.A., 2014. Two new media apple leaves agar and eggplant leaves agar for identification of Cryptococcus neoformans. Journal of Biology, Agriculture and Healthcare 4, 12-131.

188. Ali, A., 2014. Molecular study of some virulence factors of Candida albicans isolated from Iraqi candidiasis patients (MSc Thesis). College of Medicine, Al-Nahrain University, Iraq.

189. Al Sabhany, A.F.H., 2014. Study of the effect of laser rays Ndium-Yak on some dermatophytes species isolated from patients of Tikrit city (MSc Thesis). College of Science, Tikrit University, Iraq.

190. Al-Attraqchi, A.A.F., Hassan, J.S., Hadi, A.S.H., 2014. Coccidioidal meningitis: Case report. Iraqi Journal of Medical Sciences 12, 295-297.

191. Al-Fatllawy, H.J., 2014. Isolation and Identification of aerobic vaginal bacteria and fungi from adult cows in AL-Kufa district/ Al-Najaf province-Iraq. Mirror of Research in Veterinary Sciences and Animals 3, 19-23.

192. Al-Hashemi, A.J., Jibouri, M.H.A., Ghali, Z., Kdhim, B.J., 2014. Species identification and strain differentiation of dermatophyte by (GACA)4-Primer based PCR. Iraqi Journal of Science 55, 1249-1254.

193. Al-Hmadani, A.H., Al-Dhalimi, M.A., Alrufae, M.M.A., 2014. Epidemiologic study of dermatophytosis in Al-Najaf government. Magazine of Al-Kufa University for Biology 6, 53-67.

194. Al-Khafajii, K., 2014. Myco-epidemiologic and genetic study of dermatophytosis and nondermatophytes in Middle Euphrates, Iraq. African Journal of Microbiology Research 8, 2381-2386. https://doi.org/10.5897/AJMR2013.6572 
195. Almamory, I.A.A.S., Kamal, S.A.A., 2014. Bacteria and fungi associated with acute otitis media. Journal of Biology, Agriculture and Healthcare 4, 41-45.

196. Alsaidy, D.H., 2014. Isolate, Diagnosis and Treatment of Yeast Candida albicans accompanying the human body. International Journal of Advanced Research 2, 1081-1086.

197. Blyth, D.M., Mende, K., Weintrob, A.C., Beckius, M.L., Zera, W.C., Bradley, W., Lu, D., Tribble, D.R., Murray, C.K., 2014. Resistance patterns and clinical significance of Candida colonization and infection in combat-related injured patients from Iraq and Afghanistan. Open Forum Infect Dis 1, ofu109. https://doi.org/10.1093/ofid/ofu109

198. Fadhil, L., Kadim, A., Mahdi, A., 2014. Production of chitinase by Serratia marcescens from soil and its antifungal activity. Journal of Natural Sciences Research 4, 80-86.

199. Hasan, A.M., 2014. The effect of some antifungals on fungal species that isolated from leukemia patients (MSc Thesis). College of Science, University of Baghdad, Iraq.

200. Imran, Z., Ali, R., 2014. The risk of several fungi associated with bird waste. International Journal of Medical Science and Clinical Inventions 1, 558-562.

201. Jameel, G., Minnat, T., Humadi, A., Al-Ezzy, A., 2014. Hematological and histopathological effects of Ivermectin in treatment of ovine dermatophytosis in Diyala Province-Iraq 3, 1389-1394.

202. Kadhim, M., Hussainy, A. al, 2014. Isolation and identification of dermatophytes fungi from under two year children in diaber location. Al-Qadisiyah Journal of Pure Science 19, 98-109.

203. Mizher, B., 2014. Study of the mycotic mastitis in dairy goats in Al-Diwaniya province. Presented at the First Scientific conference for College of Vet. Medicine/AlQasim Green University, pp. 1-9.

204. Mohammad, K., Ismael, H., Shekhany, K., AlAttraqhchi, A., Abdullah, S., Aldabbagh, R., Denning, D., 2014. Burden of serious fungal infection in Iraq. Presented at the European Congress of Clinical Microbiology and Infectious Diseases, Barcelona.

205. Mohammed, R.M., 2014. The possible role of galactomannan antigen detection in laboratory diagnosis of invasive aspergillosis in immunocompromised patients (MSc Thesis). Collage of Science, Baghdad University, Iraq.

206. Nouri, M.A.., 2014. Study toxicity effects of Gliotoxin produced by Aspergillus fumigatus using solid state fermentation (MSc Thesis). Biotechnology/College of Science, University of Baghdad, Iraq.

207. Yehia, M.M., Abdulla, Z.A., 2014. Detection of Pneumocystis carinii (Jiroveci) from Iraqi patients with lower respiratory tract infections. Iraqi Journal of Medical Sciences 12, 126-130.

208. Abdulkareem, A.F., Lee, H.H., Ahmadi, M., Martinez, L.R., 2015. Fungal serotype-specific differences in bacterial-yeast interactions. Virulence 6, 652-657. https://doi.org/10.1080/21505594.2015.1066962

209. Ahmad, D.T., Al-Barzenji, V.B., Abdulkareem, N. Karkhi, 2015. The effects of static magnetic field and short wave ultraviolet on some pathogenic fungi. Diyala Journal of Medicine 9, 30-36.

210. Ahmed, L.T., Majeed, A., Salhi, S., 2015. The effect of mobile waves on the growth of pathogenic Fungi. International Journal of Current Microbiology and Applied Sciences 4, 838-842.

211. Ahmed, W., Kadhum, S., 2015. A study of the capability of Aspergillus species (A. niger, A. flavus and $A$. terreus) to produce phospholipase enzyme phenotypically. Al-Kufa University Journal for Biology 7, 219-224.

212. Ajaa, H.A., Abdullah, A.S., Abdul Alwahab, H.S., 2015. A study of effect some antifungals and plants extract on the growth of some dermatophytes fungi which cause ring worm diseases. Journal of the College of Basic Education, Al-Mustansyriah University 21, 165-184.

213. Ajah, H.A., 2015. New culture medium, fava bean (Vicia faba) agar, for cultivation and identification of Cryptococcus neoformans. International Journal of Advanced Research 3, 964-971.

214. Al- Dabagh, N.N., 2015. Detection of enzymatic activities of Candida species isolated from hospitalized patients in Hilla. J. of Pharmacy and Biological Sciences 10, 44-47.

215. Al-Ammari, A.M., 2015. Comparative Study between conventional and molecular detection methods of Malassezia furfur associated with Pityriasis versicolor and Psoriasis ( $\mathrm{PhD}$ Thesis). College of Science, University of Baghdad, Iraq.

216. Al-Hussainy, A. D. L., 2015. Evaluation of the antimicrobial (antibacterial and antifungal) activity of ethanolic extracts of some medical plants. Journal of Natural Sciences Research 5, 87-95.

217. Ali, H.S.H., 2015. Investigate and resistance isolates pathogenic types of yeast Candida fungal antibiotics for some indicators using ISSR genetic relationship (MSc Thesis). College of Science, Tikrit University, Iraq.

218. Ali, S.R., 2015. Study the effect of some disinfectants, sterilizers and detergents on growth of some fungi isolated from Baghdad hospitals (MSc Thesis). College of Science, University of Baghdad, Iraq.

219. Aljuboori, A.H.R., Idris, A., Al-joubory, H.H.R., Uemura, Y., Ibn Abubakar, B.S.U., 2015. Flocculation 
behavior and mechanism of bioflocculant produced by Aspergillus flavus. Journal of Environmental Management 150, 466-471. https://doi.org/10.1016/j.jenvman.2014.12.035

220. Al-Musoui, H.R.H., 2015. Study the relationship of ochratoxin A with kidney failure of unknown case in Al-Qadisiya Governorate (MSc Thesis). College of Education, Al-Qadisiya University, Iraq.

221. Alsaidy, H.A.M., Danbuss, I.K.M., Al-Zebedee, N.G., 2015. Diagnosis of some types of yeast Candida spp. isolated from patients with candidiasis in Diyala province/Iraq. Diyala Journal For Pure Science 11, 116-131.

222. Al-Shakarchi, F.I., Hussein, M.A., Al-Shaibani, A.B., 2015. Profile of microbial keratitis at a Referral Center in Iraq. Al-Nahrain Journal of Science 18, 141-147.

223. Al-Terehi, M., Al-Saadi, A.H., Abed-Neama, Z., AlAskeri, M., K.Zaidan, H., Habeeb, R.A., Majed, N., Haleem, Z., 2015. Some herbal medicinal plants activity against Candida spp which resistance to antifungal drugs. Advances in Life Science and Technology 36, 2224-7181.

224. Hasan, A., 2015. Isolation of dermatophyte species from patients with different types of leukemia in Baghdad Governorate. Iraqi Journal of Biotechnology 14, 122-126.

225. Hasan, A., AL-Jubouri, M.H., 2015. Isolation of Candida spp. from patients with different types of leukemia who suffered oral candidiasis due to their weekend immune system. Journal of Pharmaceutical, Chemical and Biological Sciences 3, 79-83.

226. Imran, Z., Al-Asadi, Y., 2015. Comparison of $25 \mathrm{~S}$ and $18 \mathrm{~S}$ primers for estimating clinical isolates of Candida diversity and evaluate their virulence in eyes infections in Iraq. Applied Science Reports 9, 166-171.

227. Imran, Z.K., Abuad, S.H., 2015. Genetic diagnosis and prevalence of urinary tract fungal pathogen with antifungal susceptibility pattern in Iraq. Journal of Advances in Medicine and Medical Research 7, 410418. https://doi.org/10.9734/BJMMR/2015/12559

228. Janabi, A.A.H.S.A., Ali, D., Mohammed, N.A., Rahem, F., 2015. In vitro antagonistic activity of Candida albicans against filamentous fungi. Medical Mycology: Open Access 1, 1-5. https://doi.org/10.21767/2471-8521.100002

229. Jasim, N., 2015. Detection of Histoplasma capsulatum in bats dropping by using Polymerase Chain Reaction (PCR) at the first time in Iraq. Journal of Natural Sciences Research 5, 57-59.

230. Kadhim, S., Aubaid, A., Al-Janabi, J., 2015. Genotyping and subgenotyping of Trichophyton rubrum isolated from dermatophytosis in Iraqi patients using RFLP-PCR. IOSR Journal of Pharmacy and Biological Sciences 10, 61-67.

231. Kadhim, S.K., Al-Janabi, J.K., Al-Hamadani, A.H., 2015. In vitro, determination of optimal conditions of growth and proteolytic activity of clinical isolates of Trichophyton rubrum. Journal of Contemporary Medical Sciences 1, 9-19.

232. Kadhum, O.H., Naher, H.S., AL-Hattab, M.K., 2015a. Clinical and histopathological study on dermatophytes infections caused by Trichophyton mentagrophytes using animal model. Journal of Natural Sciences Research 5, 170-175.

233. Kadhum, O.H., Naher, H.S., AL-Hattab, M.K., 2015 b. Prevalence of dermatophytes skin infections in Babylon Province. Journal of Natural Sciences Research 5, 182-186.

234. Mahdi, A.A., 2015. Diagnosis of and vaccin against Candida albicans "ca18" using local Elisa kit and mannan-antigen extract and purified from local strain (MSc Thesis). Collage of Health and Medical Technology, Baghdad, Middle Technical University, Iraq.

235. Mahdi, L.H., Aziz, R., Murtatha, A., Shafiq, S.A., 2015. Effect of plant extracted Salvadora persica L. on some isolated pathogens from mouth and teeth. World Journal of Pharmaceutical Research 4, 1571-1576.

236. Mezher, M., Raoof, W., Bandar, K., 2015. Isolation and identification of Candida spp. in immunocompromised patients and detection some virulence factors. Tikrit Journal of Pure Science 20, 54-60.

237. Mohamad, S., Thalij, K.M., AL-Bander, K., Dheeb, B., 2015. Survey study of the allergic fungi in Kirkuk Area and use molecular detection for identification. International Journal of Sciences 19, 383-393.

238. Mohammed, A.B., Ali, J.H., Abdullah, S.K., 2015. Identification of Candida spp. isolated from vaginal swab by phenotypic methods and multiplex PCR in Duhok, Iraq. International Journal of Research in Medical Sciences 3, 3211-3216. https://doi.org/10.18203/2320-6012.ijrms20151165

239. Mohammed, J.S., Noaimi, A.A., Sharquie, K.E., Karhoot, J.M., Jebur, M.Sh., Abood, J.R., AlHamadani, A., 2015. A survey of dermatophytes isolated from Iraqi patients in Baghdad City. AlQadisiah Medical Journal 11, 10-15.

240. Muhialdin, B.J., Hassan, Z., Bakar, F.A., Algboory, H.L., Saari, N., 2015. Novel antifungal peptides produced by Leuconostoc mesenteroides DU15 effectively inhibit growth of Aspergillus niger. Journal of Food Science 80, M1026-M1030. https://doi.org/10.1111/1750-3841.12844

241. Muhyaddin, M.O., AL-Shareafi, H.R., Allawi, S.S., 2015. Isolation and identification of antifungal 
substances producer Bacillus. Journal of the College of Basic Education, Al-Mustansyriah University 21, 3345.

242. Dheeb, B.I., Al-Mudallal, N.H., Salman, Z.A., Ali, M., Nouri, M.A., Hussain, H.T., Abdulredha, S.S., 2015. The inhibitory effects of human, camel and cow's milk against some pathogenic fungi in Iraq. Jordan Journal of Biological Sciences 8, 89-93.

243. Al-Shakarchi, F., 2015. Use of clotrimazole eye Suspension for fungal keratitis as monotherapy or sequentially with amphotercin-B. Mustansiriya Medical Journal 14, 6-13.

244. Ajah, H.A., Shafiq, S.I., 2016. Preparation of locally culture media for cultivation of fungi. Engineering \& Technology Journal 34, 141-149.

245. Aldhaher, Z., Hassan, H., Hassain, N., Shaker, R., Tawfeeq, J., Ibraheem, G., 2016. Study of fungal infection in Iraqi patients suffering from chronic cough and antifungal sensitivity test in vitro for the fungi isolated from these patients. World Journal of Pharmaceutical Sciences 4, 13-17. https://doi.org/10.13140/RG.2.2.28492.67206

246. Al-Hassani, J.M.K., Hussein, D.S., Dabi, A.K.H., 2016. Allergic fungal rhinosinusitis in patients with nasal polyposis. Iraqi Journal of Medical Sciences 14, 373-382.

247. Alhelli, A.M., Abdul Manap, M.Y., Mohammed, A.S., Mirhosseini, H., Suliman, E., Shad, Z., Mohammed, N.K., Meor Hussin, A.S., 2016. Use of response surface methodology for partitioning, one-step purification of alkaline extracellular lipase from Penicillium candidum (PCA 1/TT031). J Chromatogr B Analyt Technol Biomed Life Sci 1039, 66-73. https://doi.org/10.1016/j.jchromb.2016.10.037

248. Al-Hindi, Z.S., 2016. Evaluate The cytokine IL-1 $\alpha$ as an inflammatory indicator against isolated fungi from patients with abdominal pain. Medical Journal of Babylon 13, 479-503.

249. Ali, G.F., Al-Hamadani, A.H., Mohammad, A.W., 2016. Detection of cyclohximide resistant gene in selected pathogenic fungi. Journal of Contemporary Medical Sciences 1, 23-26.

250. Al-Janabi, A.A.H.S., Ai-Tememi, N.N., Ai-Shammari, R.A., Ai-Assadi, A.H.A., 2016. Suitability of hair type for dermatophytes perforation and differential diagnosis of $T$. mentagrophytes from $T$. verrucosum. Mycoses 59, 247-252. https://doi.org/10.1111/myc. 12458

251. Al-Jobori, K., Al-Ameed, A., Witwit, N.M., 2016. In vitro antifungal activity of musk. Didactic Journal of Medicinal Plant Research 1, 1-6.

252. Al-Laaeiby, A., Kershaw, M.J., Penn, T.J., Thornton, C.R., 2016. Targeted disruption of melanin biosynthesis genes in the human pathogenic fungus Lomentospora prolificans and its consequences for pathogen survival. Int J Mol Sci 17, 444. https://doi.org/10.3390/ijms17040444

253. Al-Maqtoofi, M., Thornton, C.R., 2016. Detection of human pathogenic Fusarium species in hospital and communal sink biofilms by using a highly specific monoclonal antibody. Environ Microbiol 18, 3620 3634. https://doi.org/10.1111/1462-2920.13233

254. Al-Saad, L.A., Al-Badran, A.I., Al-Jumayli, S.A., Magan, N., Rodríguez, A., 2016. Impact of bacterial biocontrol agents on aflatoxin biosynthetic genes, aflD and aflR expression, and phenotypic aflatoxin $\mathrm{B}_{1}$ production by Aspergillus flavus under different environmental and nutritional regimes. Int $\mathrm{J}$ Food Microbiol 217, 123-129. https://doi.org/10.1016/j.ijfoodmicro.2015.10.016

255. Fadhil, L., Haitham Seddiq, S., Abid, S., Abaas, N., 2016. Histological study of some isolation fungi from Iraq / Baghdad Hospitals apparatus that affected in liver, kidney and testes in albino mice. International Journal of Science and Research (IJSR) 6, 853-861.

256. Habib, K.A., Najee, E.N., Abood, M.S., 2016. Identification of Candida species isolated from vulvovaginal candidiasis patients by chromgen agar and PCR-RFLP method. BSJ 13, 291-297. https://doi.org/10.21123/bsj.2016.13.2.0291

257. Hasan, K., 2016. Genotypic identification of cychloheximide resistance yeasts isolated from clinical cases with superficial mycosis. International Journal of PharmTech Research 9, 501-510.

258. Hussain, A.A., 2016. Immunohistological effects of Gliotoxin produced by some pathogenic molds and yeasts in Albino male mice (PhD Thesis). Collage of Science, Baghdad University, Iraq.

259. Mohammed, A.B., Ali, J.H., Abdullah, S.K., 2016. Multiplex polymerase chain reaction identification of Candida species colonized sputum of patients suffering from various respiratory tract disorders in Duhok, Iraq. International Journal of Research in Medical Sciences 4, 1558-1563. https://doi.org/10.18203/23206012.ijrms20161227

260. Muhammed, N.I., Dabbagh, R.A., 2016. Isolation and identification of microorganisms in acne patients. Zanco Journal of Medical Sciences 20, 1330-1336.

261. Najem, M., Al-Salhi, M., Hamim, S., 2016. Study of dermatophytosis prevalence in Al-Nassiriyah city-Iraq. World Journal of Pharmaceutical Sciences 4, 166-172.

262. Risan, M.H., 2016. Molecular identification of yeast Candida glabrata from candidemia patients in Iraq. Iraqi Journal of Science 57, 808-813.

263. Risan, M.H., Muhsin, A.H., Al-Jeboury, G.H., 2016. Isolation and identification the fungus Trichophyton 
violaceum from human skin specimens in Iraq and study efficiency antibacterial and some plant essential oils. Journal of Biotechnology Research Center 10, 25 31.

264. Saleem, A.M.Y., Moho, A.A., Muneer, M., Khalil, E., 2016. Rhinocerebral mucormycosis: a review of 32 cases in Mosul. Medical Journal of Babylon 13, 366369.

265. Abbas, N., Ali, H., Abdulbaqi, N., 2017. Detection The Prevalence of adhesins and extracellular hydrolytic enzymes genes in Candida albicans Biofilm Formation. Iraqi Journal of Science 58, 988-1000.

266. Abdullah, F.O., Hussain, F.H.S., Mannucci, B., Lappano, R., Tosi, S., Maggiolini, M., Vidari, G., 2017. Composition, antifungal and antiproliferative activities of the hydrodistilled oils from leaves and flower heads of Pterocephalus nestorianus Nábělek. Chem Biodivers 14. https://doi.org/10.1002/cbdv.201700009

267. Abed Ali, F.A., Al-Janabi, J.K.A., 2017. Phenotypic and molecular identification of Trichophyton rubrum and Microsporum gypseum of dermatophytosis. Journal of Global Pharma Technology 10, 103-111.

268. Ajah, H.A., Mohammed, N.A., Abdulbaqi, N.J., 2017. Epidemiological study of Candida species among vaginal and oral Candidiasis from different clinical states. International Journal of Chem Tech Research $10,844-857$.

269. Al-Dabbagh, D.N.N., Gassim, F.-A.G., Hindi, N.K., 2017. Antimicrobial effect of sliver nanoparticles synthesized by chemical reduction on some bacteria and fungi. International Journal of Applied Engineering Research 12, 14828--14832.

270. Al-Ezzy, A.I.A., Jameel, G.H., Minnat, T.R., 2017. Isolation of Malassezia furfur and evaluation of Ivermectin and Calvatia craniiformis as a novel antifungal agent for Pityriasis Versicolor with special refer to risk factors in Iraqi patients. International Journal of Current Pharmaceutical Review and Research 8, 311-319.

271. Alhamadi, W., Al-Saigh, R.J., Al-Dabagh, N.N., AlHumadi, H.W., 2017. Oral Candida in patients with fixed orthodontic appliance: In vitro combination therapy. BioMed Research International 2017, 1-8. https://doi.org/10.1155/2017/1802875

272. Ali, I.A., 2017. Isolation, identification and determination of antifungal sensitivity of fungi isolated from a sample of patients with rhinosinusitis in Baghdad city. Iraqi Journal of Medical Sciences 15, 64-70.

273. Al-Khafaji, Z.K.A., 2017. Characterization of some virulence factors and gene expression of Secreted Aspartyl proteinase in Candida albicans isolated from oral candidiasis in cancer patients ( $\mathrm{PhD}$ Thesis). College of Education, University of Al-Qadisiya, Iraq.

274. Alsudani, A., 2017. The effect of some antiseptics on molds and yeasts isolated from wards in Al-Diwaniya Teaching Hospital, Iraq. Journal of Pure and Applied Microbiology https://doi.org/10.22207/JPAM.11.1.03

275. Alzahraa, F., Al-Janabi, J., 2017. Phenotypic and molecular identification of Trichophyton rubrum and Microsporum gypseum of dermatophytosis. Journal of Global Pharma Technology 10, 103-111.

276. Alzahraa, F., Al-Janabi, J., Alhattab, M., 2017. Prevalence of dermatophyte fungal infection in Hillah, Iraq. International Journal of ChemTech Research 10, 827-837.

277. Al-Ziadi, S., Mahmood, H., 2017. The effect of silver bio-nanoparticles synthesized by Curcuma longa $\mathrm{L}$. on pathogenic fungi. International Journal of PharmTech Research 10, 508-514.

278. Amin, H.I.M., Amin, A.A., Tosi, S., Mellerio, G.G., Hussain, F.H.S., Picco, A.M., Vidari, G., 2017. Chemical composition and antifungal activity of essential oils from flowers, leaves, rhizomes, and Bulbs of the Wild Iraqi Kurdish Plant Iris persica. Nat Prod Commun 12, 441-444.

279. Anwer, S.S., Ali, G.A., Hamadamin, C.Z., Jaafar, H.Y., 2017. Isolation and identification of fungi from fast food restaurants in Langa Bazar. IJEAB 2, 1517-1522. https://doi.org/10.22161/ijeab/2.4.10

280. Fadhil, L., Hashim, T., Hussain, A., Helal, Z., Almuttwaki, L., 2017. Effect of some isolation fungi from Iraq / Baghdad hospitals apparatus on physiology of liver, kidney and testis in Albino mice. International Journal of Science and Research (IJSR) 6, 300-303. https://doi.org/10.21275/ART20176591

281. Farhan, R.K., Ahmed, Th., Mohammad, S.I., 2017. Epidemiology of cutaneous candidiasis among patients attending Tikrit Teaching Hospital. The Medical Journal of Tikrit University 22, 212-219.

282. Fuad, A., Sulaiman, G., Dheeb, B., Hashim, A., Haitham Seddiq, S., 2017. Improving conditions for Gliotoxin production by local isolates of Aspergillus fumigates. Journal of biotechnology research center 11, 14-24.

283. Hadibarata, T., Khudhair, A.B., Kristanti, R.A., Kamyab, H., 2017. Biodegradation of pyrene by Candida sp. S1 under high salinity conditions. Bioprocess Biosyst Eng 40, 1411-1418. https://doi.org/10.1007/s00449-017-1798-7

284. Hamad, I., Ranque, S., Azhar, E.I., Yasir, M., JimanFatani, A.A., Tissot-Dupont, H., Raoult, D., Bittar, F., 2017. Culturomics and amplicon-based metagenomic approaches for the study of fungal population in human 
gut microbiota. Sci Rep 7, 16788. https://doi.org/10.1038/s41598-017-17132-4

285. Hamada, T.A., 2017. The effect of aspirin as antifungal drug against some medical important fungi in in vitro. The Medical Journal of Tikrit University 22, 185-189.

286. Hameed, A., Ahmed, L., Ali, S., 2017. Molecular and genotypes identification of C. albicans isolated from children with diarrhea in Diyala province-Iraq. International Journal of Bio-Technology 7, 1-10. https://doi.org/10.24247/ijbtrdec20171

287. Hasan, A.M., Abdul Majeed, S.M., 2017. Isolation and identification of opportunistic fungi from patients with different types of leukemia in Baghdad province. Iraqi Journal of Biotechnology 16, 216-222.

288. Hmood, B.A., 2017. Detection of Gliotoxin in patients with pulmonary aspergillosis. Journal of University of Babylon 25, 639-650.

289. Hussein, H., Abdullah, S., 2017. Keratinolytic and Opportunistic pathogenic fungi from carpet dust in mosques and residential houses in Duhok, Kurdistan Region, Iraq. SJUOZ 5, 16-19. https://doi.org/10.25271/2017.5.1.293

290. Jalil, W.I., 2017. Clinical and epidemiological investigation of bovine dermatophytosis in Diyala Province. Al-Anbar Journal of Veterinary Sciences 10.

291. Jameel, G.H., Al-Ezzy, A.I.A., 2017. Evaluation of Antifungal activity of Calvatia craniiformis and IverMectin as novel alternative therapies for Aspergillus niger associated acute otitis media with special refer to sociodemographic factors among rural children of Diyala Province-Iraq. IJPCR 9, 581-589. https://doi.org/10.25258/ijpcr.v9i08.9583

292. Jameel, Z., Fuad, A., Al-Mahdawi, M., Alkerim, N., Alrahman, E., 2017. Bioactivity of pyocyanin of Pseudomonas aeruginosa clinical isolates against a variety of human pathogenic bacteria and fungi species. The International Arabic Journal of Antimicrobial Agents 7, 1-7. https://doi.org/10.3823/0812

293. Kelkawi, A.H.A., Abbasi Kajani, A., Bordbar, A., 2017. Green synthesis of silver nanoparticles using Mentha pulegium and investigation of their antibacterial, antifungal and anticancer activity. IET nanobiotechnol. 11, 370-376. https://doi.org/10.1049/iet-nbt.2016.0103

294. Khalaf, S., Ariffin, Z., Husein, A., Reza, F., 2017. Surface coating of gypsum-based molds for maxillofacial prosthetic silicone elastomeric material: evaluating different microbial adhesion: Journal of Prosthodontics 26, 664-669. https://doi.org/10.1111/jopr.12460

295. Maikhan, H.K., Habeb, K.A., Suleiman, A.A., 2017. Isolation and molecular identification of Trichophyton rubrum var. raubitschekii from the infant Groin.
Journal of Garmian University 4, 615-623. https://doi.org/10.24271/garmian.169

296. Mohammed, A., Ali, J.H., Abdullah, S.K., 2017. Identification of Candida spp. isolated from urine by phenotypic methods and Multiplex PCR in Duhok, Iraq. Science Journal of University of Zakho 1, 11-15.

297. Mohammed, L.M., Salah, T.F.M., Qader, K.O., 2017. Chemical composition and antifungal activity of Mentha spicata L. plant from Sulaimaniyah in Iraq. Kurdistan Journal of Applied Research 2, 52-56. https://doi.org/10.24017/science.2017.1.11

298. Obaid, A., Al-Janabi, J., Taj-Aldin, W., 2017a. antifungal activity of anise essential oil against growth and morphological characteristics of Trichophyton rubrum. Journal of Global Pharma Technology 7, 5368.

299. Obaid, A., Al-Janabi, J., Taj-Aldin, W., 2017b. Chemical composition and bioactivity characteristics of Pimpinella anisum essential oil against Trichophyton rubrum. Journal of Global Pharma Technology 8, 44-56.

300. Saleem, S.S., Alnakshabandie, W.M., Saadullah, A.A.M., 2017. Fungal contamination of Azadi Teaching Hospital and Hevi Paediatric Hospital Environments, Duhok, Iraq. Tikrit Journal of Pure Science 22, 39-45.

301. Shibli, M.K.A.A.-, AL-Zamili, I.A.A.R., 2017. Investigation of fungi associated with pet birds and test sensitivity toward fungal antibiotics. Al-Qadisiyah Journal of Pure Science 22, 553-562.

302. Touhali, I.S., Hassan, J.S., 2017. Detection of pulmonary candidiasis in immunocompromised Iraq patients by conventional polymerase chain reaction technique. Journal of Wassit for Science \& Medicine 10.

303. Touhali, I.S., Mohsin, Z.H., AL-Ruaby, K.J.W., 2017. Molecular Detection and Identification of Aspergillus fumigates from Goats in Waist Governorate of Iraq. Journal of Biology, Agriculture and Healthcare 7, 64.

304. Al- Tameemi, K.A.H., 2018. Colonization of Pathogenic microbes on contaminated Nebulizer devices for respiratory tract diseases at emergency department in hospitals. Journal of Natural Sciences Research 8.

305. Alalwan, H., Nile, C.J., Rajendran, R., McKerlie, R., Reynolds, P., Gadegaard, N., Ramage, G., 2018. Nanoimprinting of biomedical polymers reduces candidal physical adhesion. Nanomedicine: Nanotechnology, Biology and Medicine 14, 10451049. https://doi.org/10.1016/j.nano.2018.01.011

306. Al-Ammari, A.M., Al-Attraqhchi, A.A.F., Al-Ahmer, S.D., 2018. Molecular characterization of Malassezia furfur isolated from patients with pityriasis versicolor 
compared to healthy control in Baghdad, Iraq |. Journal of the Faculty of Medicine Baghdad 58, 85-89.

307. Al-Bader, S.M., 2018. The hygienic importance of fungi colonizing the sheep wool in Erbil/Iraq. Virol Mycol 07, 1-7. https://doi.org/10.4172/21610517.1000177

308. Albadr, A., Coulter, S., Porter, S., Thakur, R., Laverty, G., 2018. Ultrashort self-assembling peptide hydrogel for the treatment of fungal infections. Gels 4, 48 . https://doi.org/10.3390/gels4020048

309. Al-Bahrani, R., Majeed, S., Owaid, M.N., Mohammed, A.B., Rheem, D.A., 2018. Phyto-fabrication, characteristics and anticandidal effects of silver nanoparticles from leaves of Ziziphus mauritiana Lam. https://doi.org/10.23893/1307-2080.APS.05620

310. Al-Charrakh, A.H., Al-Mamory, Z.O., Al-Malaky, K.A., 2018. Antifungal susceptibility patterns of Aspergillus species isolated from patients with pulmonary diseases in Iraq. Journal of Applied Pharmaceutical Science 8, 88-93.

311. Aldory, M.E.I., Ali, F.F., Sultan, S.M., 2018. Effective of watery and alcoholic extract of Frankincense on the Candida albicans fungus. International Journal of Pharmaceutical Research and Allied Sciences 7, 5662.

312. AlFindee, M.N., Zhang, Q., Subedi, Y.P., Shrestha, J.P., Kawasaki, Y., Grilley, M., Takemoto, J.Y., Chang, C.-W.T., 2018. One-step synthesis of carbohydrate esters as antibacterial and antifungal agents. Bioorganic \& Medicinal Chemistry 26, 765774. https://doi.org/10.1016/j.bmc.2017.12.038

313. Al-Mendalawi, M.D., 2018. Aspergillus sinusitis complicated with meningitis and multiple cerebral infarctions in immunocompetent patient. NSJ 23, 354354. https://doi.org/10.17712/nsj.2018.4.20180273

314. Al-qertani, Y.M., Mohammed, S.M., 2018. Antifungal Activity of Acetonic Extracts of Syzygium aromaticum ' Flowers and Mentha longifolia's Leaves Against Clinical Isolates of Candida albicans. https://doi.org/10.24237/djps.1402.448b

315. Alsharifi, E.A., 2018. Epidemiology of vaginal candidiasis among pregnant women attending Tikrit teaching hospital/Iraq. Journal of Faculty of Medicine, Baghdad University 59, 321-324.

316. Al-Shuhaib, M.B.S., Albakri, A.H., Alwan, S.H., Almandil, N.B., AbdulAzeez, S., Borgio, J.F., 2018. Optimal PCR primers for rapid and accurate detection of Aspergillus flavus isolates. Microbial Pathogenesis 116, 351-355.

https://doi.org/10.1016/j.micpath.2018.01.049

317. Al-Tekreeti, A.R.A., Al-Halbosiy, M.M.F., Dheeb, B.I., Hashim, A.J., Al-Zuhairi, A.F.H., Mohammad, F.I., 2018. Molecular identification of clinical Candida isolates by simple and randomly amplified polymorphic DNA-PCR. Arab J Sci Eng 43, 163-170. https://doi.org/10.1007/s13369-017-2762-1

318. Alzubaidy, T.S., Mohammed, A.J., Al-Gburi, A.A.H., 2018. Comparison of two conventional methods for identification of dermatophyte fungi. Ibn Al-Haitham Journal for Pure and Applied Science 31, 21-30.

319. AL-Zuhairi, A.F.H., 2018. Isolation and identification of pathogenic fungi from diabetic patients in Diyala. Biochem. Cell. Arch. 18, 959-966.

320. Ammari, A.M., Talib, N.Th., Fuad, A., H., AbdulRahman, E.S., 2018. Association of Malassezia furfur with Onychomycosis patients In Baghdad, Iraq. Diyala Journal of Medicine 14, 115-122.

321. Dwaish, A., Mohammed, D., Alwan, A., Lefta, S., 2018. Anti-dermatophytes activity of Macroalgal extracts (Chara vulgaris) isolated from Baghdad CityIraq. Journal of Global Pharma Technology 10, 759766.

322. Essa, M.A., Hussein, F.H., 2018. Isolation and identification of some microorganisms causing vaginitis and cervicitis and relationship of Risk factors with these infections. Rafidain Journal of Science 27, 77-94. https://doi.org/10.33899/rjs.2018.159378

323. Hashim, H.R., Ali, W.J.A., Walli, H.A., 2018. Detection of contamination by opportunistic fungi in solid and liquid soaps in special medical labs and investigation of ability to producing toxins. Journal of Pharmaceutical Sciences and Research 10, 2346-2350.

324. Hassan, A.A., Hameed, M.S., Al-Ezzy, A.I.A., 2018. Correlation between aspergillosis and renal function profile analysis in broilers of Diyala province - Iraq. Diyala Journal of Agricultural Sciences 10, 177-193.

325. Hussein, H., 2018. Isolation and detection of Candida tropicalis from aborted placenta in Al-Najaf city/Iraq. International Journal of Pharmaceutical Quality Assurance 9, 204-207. https://doi.org/10.25258/ijpqa.v9i2.13648

326. Islam, T.A.B., Majid, F., Ahmed, M., Afrin, S., Jhumky, T., Ferdouse, F., 2018. Prevalence of dermatophytic Infection and Detection of Dermatophytes by Microscopic and Culture Methods. Journal of Enam Medical College 8, 11-15. https://doi.org/10.3329/jemc.v8i1.35429

327. Kadhim, O.H., 2018. The incidence of dermatophytosis in Babylon Province, Iraq. Medical Journal of Babylon 15, 234. https://doi.org/10.4103/MJBL.MJBL_76_18

328. Khalid, G., Ali, H., 2018. Antagonistic activity of silver nanoparticles synthesis by Fusarium oxysporum against Candida spp. Pakistan Journal of Biochemistry $15,347-356$.

329. Muslim, S. N., Kadmy, I.M.S.A., Ali, A.N.M., Salman, B.K., Ahmad, M., Khazaal, S.S., Hussein, N.H., 
Muslim, Sraa Nsayef, 2018. Chitosan extracted from Aspergillus flavus shows synergistic effect, eases quorum sensing mediated virulence factors and biofilm against nosocomial pathogen Pseudomonas aeruginosa. Int J Biol Macromol 107, 52-58. https://doi.org/10.1016/j.ijbiomac.2017.08.146

330. Najem, A.M., 2018. Contaminated fungi in the biology department laboratories and antagonistic potentiality of Myrtrus communis volatile oil against the isolated fungi. Al-Nahrain Journal of Science 21, 126-130.

331. Rasul, H.O., 2018. Current antifungal drug recommendations to treat oral thrush in Sulaimani City-Iraq. UHD Journal of Science and Technology 2, $1-6$.

332. Subedi, Y.P., Alfindee, M.N., Shrestha, J.P., Becker, G., Grilley, M., Takemoto, J.Y., Chang, C.-W.T., 2018. Synthesis and biological activity investigation of azole and quinone hybridized phosphonates. Bioorganic \& Medicinal Chemistry Letters 28, 3034-3037. https://doi.org/10.1016/j.bmcl.2018.08.002

333. Taha, B., Dakhil, M.H., Almutairy, T., 2018. Manuscripts preserved at the Al-Hussein Holy shrine: Isolation and diagnosis of fungi causing potential damage. Indian Journal of Ecology 45, 214-221.

334. Touhali, I.S., 2018. Isolation and identification of some opportunistic fungi from camels in Wasit governorate of Iraq. Journal of Pure and Applied Microbiology 12, 801-805.

335. Twede, J.V., Peters, K.M., 2018. Primary cutaneous cryptococcosis in an immunocompetent Iraq War veteran. Cutis 102, E30-E31.

336. A. Albaqi, M.A., Saber, A., Fathel, A., 2019. The Influence of molecular Effects on Laser Nd:YAG and Diode on Trichophyton rubrum fungi using RAPD marker. Tikrit Journal of Pure Science 24, 117-125. https://doi.org/10.25130/j.v24i6.896

337. Abdullah, M.H., Al-Janabi, J.K., 2019. Efficiency of antifungal agents with culture filtrates of two basidiomycetes fungi on growth and on citrate and isocitrate genes of Trichophyton rubrum. Drug Invention Today 11, 3085-3096.

338. Al-Oebady, M. A. H., Hanfoosh, H. S., Jabbar, A. M., Witwit, S. S., 2019. Effect of fixed orthodontic appliances on the change of the oral bacteria and Candida species in AL-Samawah city, Iraq. Journal of Pharmaceutical Sciences and Research 11(3), 10921096.

339. AL-Ammari, A.M., 2019. Investigation of fungi resistant to disinfectants used in burn units at Baquba Teaching Hospital. Indian Journal of Public Health Research \& Development 10, 1612-1616.

340. Al-Ammari, A.M.M., Hussain, A.F., Ismael, T., 2019. Prevalence of fungal pathogens among respiratory tract infections. Annals of Tropical Medicine and Public Health 22, 38-44. https://doi.org/10.36295/asro.2019.22085

341. Al-Attraqchi, A.A.F., 2019. Editorial medicinal fungi. Iraqi Journal of Medical Sciences 17, 1-3.

342. Al-Attraqchi, A.A.F., Sahib, H.B., Al-Hasseni, J.M.K., Mohammed, M.M., 2019. 2.The vitro study effect of ginger extracts on fungal isolated from a suppurative otitis media and externa. Iraqi Journal of Medical Sciences 17, 4-11.

343. Al-Azzawi, A.K.A., 2019. Isolation and molecular identification of some Malassezia spp. isolated from dogs and human infected with pityriasis versicolor in Diyala Province (MSc Thesis). College of Veterinary Medicine, University of Diyala, Iraq.

344. Al-Daamy, A.A., Hussein, F., Saad, F., 2019. Study of the relationship between blood parameters with skin mycoses. https://doi.org/10.37623/sjmr.2019.31005

345. Al-Fakih, A.M., Algamal, Z.Y., Lee, M.H., Aziz, M., Ali, H.T.M., 2019. QSAR classification model for diverse series of antifungal agents based on improved binary differential search algorithm. SAR and QSAR in Environmental Research 30, 131-143. https://doi.org/10.1080/1062936X.2019.1568298

346. Alffayyadh, I.H., Khudhair, I.M., Jaber, A.S., 2019. Isolation and diagnosis of fungi from blood and skin samples in Dhi-Qar Province. Indian Journal of Public Health Research \& Development 10, 965-968. https://doi.org/10.5958/0976-5506.2019.02947.4

347. Alhoot, M.A., Eltariki, F.E.M., Ridzuan, P.M., Tiwari, K., Wang, S.M., 2019. The inhibitory effect of the Mentha piperita leaves extracts on the mycotoxin producer aspergillus niger. Int. J. Med. Tox. \& Leg. Medi. 22, $179 . \quad$ https://doi.org/10.5958/09744614.2019.00038.X

348. Mohammed, B.A., Mohammed, B. L., Khorsheed, M. B., 2019. Detection of Candida albicans in females urinary tract Infection by using microscopical and cultural methods of urine samples in Kirkuk city -Iraq. Journal of Global Pharma Technology 11, 640-644.

349. Ali, R., Hameed, Z.H., Hussain, A.F., Hamu, A., 2019. Evaluation effectiveness of fluconazole and Mirabilis jalapa extract against some pathological fungi. Biochemical and Cellular Archives 19, 2467-2473.

350. Ali, R.N., AL-Janabi, A.A.S., 2019. Asthma and Aspergillosis: Which one causes the other? International Journal of Medical Reviews 6, 140-145. https://doi.org/10.30491/ijmr.2019.101967

351. AL-Janabi, A.A.H.S., Al-Mosawe, H.A.S., AIMoswai, K., 2019. Tamoxifen: from anti-cancer to antifungal drug. International Journal of Medical Reviews 6, 88-91. https://doi.org/10.29252/IJMR060304 
352. Al-Janabi, A.A.H.S., Bashi, A.M., 2019. Development of a new synthetic xerogel nanoparticles of silver and zinc oxide against causative agents of dermatophytoses. Journal of Dermatological Treatment 30 , 283-287. https://doi.org/10.1080/09546634.2018.1506079

353. Al-Nasrawi, H., 2019. Candida of medical importance isolated from cancer patients. Indian Journal of Forensic Medicine \& Toxicology 13, 1095. https://doi.org/10.5958/0973-9130.2019.00446.8

354. Alshawi, H., Al-Zubaidi, S.K., Al-Khafaji, M.M., 2019. Evaluation and investigation of the Prevalence of superficial mycosis among primary schools pupils in Al-Dewaniyah Governorate, Iraq. Journal of Global Pharma Technology 11, 391-395.

355. Alshibly, M.K., zamily, I. ali al, Fazil, N., 2019a. Survey of fungi found in books on the shelves of the libraries of the University of Qadisiyah - Iraq. IOP Conf. Ser.: Mater. Sci. Eng. 571, 012042. https://doi.org/10.1088/1757-899X/571/1/012042

356. Alshibly, M.K., Zamily, I.A.A., Haider, R., 2019 b. Antibiotic sensitivity of fungi isolated from patients with sinusitis. Scientific Journal of Medical Research 3, 64-69.

357. Al-Shuhaib, M.B.S., Al-Kaaby, H.N., Alwan, S.L., 2019. A highly efficient electrophoretic method for discrimination between two Neoscytalidium species using a specific fungal internal transcribed spacer (ITS) fragment. Folia Microbiol 64, 161-170. https://doi.org/10.1007/s12223-018-0641-0

358. Alsudani, A.A., Mohammed, G.J., Al-Awsi, G.R.L., 2019. In vitro, the antimicrobial activity of some medicinal plant extracts on the growth of some bacterial and fungal pathogens. J. Phys.: Conf. Ser. 1294, 062099.

359. Alwan, D.S., 2019. Anti-fungal activity of ginger oil against Aspergillus fumigatus and Aspergillus niger causing aspergillosis. Indian Journal of Public Health Research \& Development 10, 847-851.

360. Al-Zubaidi, S.K., 2019. Detection of ctolysis peptide toxin gene (Candidalysin) in Candida albicans isolates. Indian Journal of Public Health Research \& Development 10, 2159-2162.

361. Awad, A.K., Al-Ezzy, A.I.A., Jameel, G.H., 2019. Phenotypic identification and molecular characterization of Malassezia spp. isolated from Pityriasis versicolor patients with special emphasis to Risk Factors in Diyala Province, Iraq. Open Access Maced J Med Sci 7, 707-714. https://doi.org/10.3889/oamjms.2019.128

362. Dahham, M.T., Omar, A. a. K.F., Dheeb, B.I., 2019. Synergistic effect of tea tree oil on fungi causing vaginal thrush in pregnant women. Journal of Biotechnology Research Center 13, 35-44.

363. Dheeb, B.I., Al-dujayli, S.M.A., Ibrahim, I.M., Abbas, Q.A., Ali, A.H., Ramizy, A., Eisa, M.H., Aljameel, A.I., Ali, I.M., Khashman, B.M., Hussain, A.F., 2019. Study the antifungal activity of $\mathrm{ZnS}: \mathrm{Mn}$ nanoparticles against some isolated pathogenic fungi. J. Phys.: Conf. Ser. 1178, 1-11. https://doi.org/10.1088/17426596/1178/1/012008

364. El-Sayed, A.S.A., George, N.M., Yassin, M.A., Alaidaroos, B.A., Bolbol, A.A., Mohamed, M.S., Rady, A.M., Aziz, S.W., Zayed, R.A., Sitohy, M.Z., 2019. Purification and characterization of ornithine decarboxylase from Aspergillus terreus; Kinetics of inhibition by various inhibitors. Molecules 24, 2756. https://doi.org/10.3390/molecules24152756

365. Gharib, S.J., Abdullah, S.K., Richardson, M.D., 2019. Auxarthron alboluteum related to non-dermatophytic toenail infection in Kurdistan region, Iraq: A case report. Med Mycol Case Rep 26, 53-56. https://doi.org/10.1016/j.mmcr.2019.10.006

366. Gharib, S.J., Tahir, N.A., 2019. Molecular Identification of Fusarium proliferatum from toenails: A case report. Kurdistan Journal of Applied Research 4 , 128-137. https://doi.org/10.24017/science.2019.ICHMS.13

367. Hadi, D.H., 2019. The effect of Trigonella foemungracum extract on the fungi that isolated from the libraries door. Journal of University of Babylon for Pure and Applied Sciences 27, 45-51.

368. Hameed, F., A., 2019. Clinical study of some bacteria and fungi that cause vaginitis in Al-Khalis City. Indian Journal of Forensic Medicine \& Toxicology 13, 12951300 . https://doi.org/10.5958/09739130.2019 .00479 .1

369. Hindy, N., Abiess, A.A., 2019. Isolation and identification of dermatophytes causing dermatophytosis in Hilla city, Iraq. Indian Journal of Public Health Research \& Development 10, 22252230. https://doi.org/10.5958/09765506.2019 .03185 .1

370. Hussein, H.S., Dheeb, B.I., Hamada, T.A., 2019. Studying the Candida resistance and sensitivity for some antifungals. Journal of Biotechnology Research Center 13, 26-34.

371. Jaberi, A.K.H., Alajeely, A.A.A., Ail, Y.M., 2019. Inhibition of Candida fungi and $E$. coli bacteria in Zein nanoparticles conjugated with silver ion $(\mathrm{Ag} 0+)$. Indian Jour. of Foren. Med. \& Toxicol. 13, 969. https://doi.org/10.5958/0973-9130.2019.00424.9

372. Jasim, A.A., Mohammed, B.T., Lahuf, A.A., 2019. Molecular and enzymatic properties of fungi isolated from historical manuscripts preserved at the Al- 
Hussein holy shrine. Biochem. Cell. Arch. 19, 42954305. https://doi.org/10.35124/bca.2019.19.2.4295

373. Khalaf, S., Mejbel, F.A., 2019. Phenotypic and genotypic diagnosis of Candida albicans isolated from different sources. Plant Archives 19, 594-597.

374. Khazia, M., Al-Janabi, J., 2019. Antifungal activity of combination of medicinal plant extracts with terbinafine through regulating subtilisin virulence genes in Microsporum canis. Drug Invention Today 12, 2580-2588.

375. Lafta, A.K., Ajah, H.A., Dakhil, O. a. A., Al-Wattar, W.M.A., 2019. Biosynthesis of silver nanoparticles using biomass of Cladosporium cladosporioides and antifungal activity against pathogenic fungi causing onychomycosis. Plant Archives 19, 4391-4396.

376. Minnat, T.R., 2019. Epidemiological, clinical and laboratory study of Canine dermatophytosis in Baghdad Governorate, Iraq. The Iraqi Journal of Veterinary Medicine 43, 183-196. https://doi.org/10.30539/iraqijvm.v43i1.489

377. Mohamed, K.J., AL-Janabi, A.A.S., 2019. Inhibitory action of pyocyanin against human pathogenic bacteria and fungi. International Journal of Medical Science and Current Research (IJMSCR) 1, 159-167.

378. Mohammed, F., Pehlivan, M., Sevindik, M., 2019. Antioxidant, antibacterial and antifungal activities of different extracts of Silybum marianum collected from Duhok (Iraq). International Journal of Secondary Metabolite 6, 317-322. https://doi.org/10.21448/ijsm.581500

379. Mohammed, R.A., 2019. Effect of Mirabilis jalapa L. extracts in comparison with Fluconazole on some fungal isolates from blood and urine samples of patients with renal failure (MSc Thesis). College of Science, University of Diyala.

380. Mohammed, T. K., Wahab, K.M., Jawad, M.A., 2019. Isolation and identification of Candida albicans in different clinical samples. Al-Nisour Journal for Medical Sciences 1, 85-97.

381. Mohammed, T.K., Jawad, M.A., Kamal, O., Abbas, A.H., Alabbas, A.S., 2019. Isolation of some pathogenic bacteria and fungi from student's mobile phones (Part I). Indian Journal of Public Health Research \& Development 10, 2108-2112. https://doi.org/10.5958/0976-5506.2019.03162.0

382. Nasser, N.I., Habeeb, T.A., Al-Hadrawi, M.K., 2019. Etiological agent and risk factor of otomycosis at Essaouira, west province, Iraq. Biochemical and Cellular Archives 19, 1777-1781.

383. Sahib, R.A., 2019. Effects of Zinc oxide nanoparticles on the growth inhibition of fungi isolated from cream cosmetics. Rese. Jour. of Pharm. and Technol. 12, 123. https://doi.org/10.5958/0974-360X.2019.00024.6
384. Salman, I.S., Ali, H., Slman, J.A., Yass, A., 2019. Preparation of denture cleanser to protect dentures from Candida albicans contamination by the use of locally produced Levan. Iraqi Patent No. 5946.

385. Salman, J. a. S., Ajah, H.A., Khudair, A.Y., 2019. Analysis and characterization of purified levan from Leuconostoc mesenteroides ssp. cremoris and its effects on Candida albicans virulence factors. Jordan Journal of Biological Sciences (JJBS) 12, 243-250.

386. Sattar, OmarD.A., Fadhel, S.R., Ismael, T.K., Hussain, A.F., 2019. Antifungal Activity of Boswellia serrata Gum Extracts on Antifungal Drugs Resistant Aspergillus fumigatus isolated from Diyala Patients. Ind. Jour. of Publ. Health Rese. \& Develop. 10, 49294934. 5506.2019 .03930 .5 https://doi.org/10.5958/0976-

387. Shafiq, S.A., Aljuraisy, Y.H., 2019. Prevalence of fungal contamination in some of biology department's laboratories. Asian Journal of Pharmaceutical Research and Development 7, 36-39. https://doi.org/10.22270/ajprd.v7i3.490

388. Taher, F., 2019. Antifungal activity of Eucalyptus microtheca leaves extract against aflatoxigenic fungi. International Journal of Pharmaceutical Quality Assurance 10, 81-84. https://doi.org/10.25258/ijpqa.10.3.27

389. Zangana, A.J.M., Huseen, D.A., Latef, R.H., 2019. Investigation of infectious stages of intestinal parasites and fungal spores which contaminated nails of some students in Tikrit University / Iraq. Indian Journal of Public Health Research \& Development 10, 1204 1207.

390. Abdullah, S.M.Z., 2020. Prevalence of Candida spp. from in women with vulvovaginal infection in Maternity teaching hospital in Erbil, Iraq. Iraq Medical Journal 4, 16-22.

391. Ahmad, T.A., Al-Mahdawe, M.M., Nadir, D.S., 2020. Influence of the extract of biotic elicitor Aspergillus niger on the production of furanocoumarins in callus cultures of Ruta graveolens. Plant Archives 20, 4633 4638.

392. Ahmed, L.T., Darweesh, Z.A., Hussain, W.M., 2020. Prevalence of dermatophytes fungal infection among different gender. Indian Journal of Forensic Medicine \& Toxicology 14, 1717-1722. https://doi.org/10.37506/ijfmt.v14i2.3184

393. Ajah, H.I., Hassan, A.S., Rahi, G.K., 2020. Isolation and identification of Candida species from oral and vaginal and determination of virulence factor. Plant Archives 20, 2697-2706.

394. AL-abedi, H.F.H.A., AL-Attraqchi, A.A.F., Khudaier, B.Y., 2020. Evaluation the enzymatic activites of Candida albicans and Candida parapasilosis isolated 
from bovine mastitis in Basrah Province Iraq by API ZYM test. Presented at the International Conference of Numerical Analysis and Applied Mathematics (ICNAAM 2019), Rhodes, Greece, pp. 020014020014-8. https://doi.org/10.1063/5.0027653

395. AlAmery, S.F., AlGaraawi, N. lmtair, 2020. Phytochemical profile and antifungal activity of stems and leaves methanol extract from the Juncus maritimus Linn. Juncaceae family against some dermatophytes fungi. AIP Conference Proceedings 2290, 020034. https://doi.org/10.1063/5.0027554

396. AL-Ammari, A.M., Hussein, A.F., 2020. Occurrence of Rhodotorula mucilaginosa among immunocompromised patients with different infections. Indian Journal of Forensic Medicine \& Toxicology 14, 2185-2189. https://doi.org/10.37506/ijfmt.v14i4.11875

397. Al-Ani, Y.M.M., 2020. Study of tinea pedis in diabetic versus non-diabetic patients. Al-Kindy College Medical Journal 16, 78-102.

398. Alfayyadh, I.H., Khudhair, I.H., 2020. Comparative study to compare the prevalence of Aspergillus flavus in Iraq and some neighboring countries. Indian Journal of Forensic Medicine \& Toxicology 14, 2529-2534. https://doi.org/10.37506/ijfmt.v14i3.10818

399. Alharthi, A.M., Lee, M.H., Algamal, Z.Y., Al-Fakih, A.M., 2020. Quantitative structure-activity relationship model for classifying the diverse series of antifungal agents using ratio weighted penalized logistic regression. SAR and QSAR in Environmental Research 31, 571-583. https://doi.org/10.1080/1062936X.2020.1782467

400. Ali, H., Mohammed, S., Aja, H., 2020. Preparation of a new culture medium from Avena sativa for cultivation of some microorganisms. Plant Archives 20, 4337-4340.

401. AL-Khikani, F.H.O., 2020. Challenges in fungal treatment: A serious public health problem. Indian Journal of Medical Specialties 11, 171. https://doi.org/10.4103/INJMS.INJMS_32_20

402. Al-Khikani, F.H.O., Almosawey, H.A.S., Abdullah, Y.J., Al-Asadi, A.A., Hameed, R.M., Hasan, N.F., AlIbraheemi, M.K.M., 2020. Potential antiviral properties of antifungal drugs. Journal of the Egyptian Women's $\begin{array}{lll}\text { Dermatologic Society } & 17 . & \end{array}$ https://doi.org/10.4103/JEWD.JEWD_40_20

403. Aldossary, M.A., Abdulraheem, B.S., Almansour, N.A., Al-Abbas3, M.J.A., 2020. Thirteen new yeast strains isolated from cancer patients in Basrah-Iraq by ITS rDNA Sequencing. Indian Journal of Forensic Medicine \& Toxicology 14, 877-882. https://doi.org/10.37506/ijfmt.v14i1.163
404. Al-Masaoodi, N.N.H., Al-Janabi, J.K.A., Mohammed, B.T., 2020. Molecular characterization and gene expression profiling of Trichophyton rubrum treated with a Marasmius palmivorus filtrate. Drug Invention Today 14, 109-119.

405. Alnasrawi, H., 2020a. Mycobiota and enteric viruses among infants with acute diarrhea in Iraq. Indian Journal of Public Health Research \& Development 11, 2167-2171. https://doi.org/10.37506/ijphrd.v11i2.3450

406. Alnasrawi, H., 2020b. Opportunistic mycoses among hepatitis patients in Iraq. Eurasian Journal of Biosciences 14, 3653-3656.

407. Alwan, A.H., Abdulkareem, A., Alwan, B.H., 2020. Antifungal effect of Lactobacillus acidophilus crude extract. PalArch's Journal of Archaeology of Egypt / Egyptology 17, 7616-7622.

408. Al-Wattar, W.M.A., 2020. Overview on common fungal infections, recovered in Baghdad teaching hospitals in five years. Iraq Med $\mathrm{J} 4$. https://doi.org/10.22317/imj.v4i2.819

409. Awad, F.M., Al-Samarrai, A.M., Dheeb, B., 2020. Study of the inhibitory effects of rheum ribes extracts on a pathogenic fungi and cancer cell line. Plant Archives 20, 3161-3168.

410. Azeez, D.A., 2020. Antifungal activity of mixture Eugenia aromaticum and Thymus vulgaris essential oils against Candida albicans clinical strains in AlMuthanna Province. Indian Journal of Public Health Research \& Development 11, 1184-1187. https://doi.org/10.37506/ijphrd.v11i4.8871

411. Dhedan, A., Mahmood, N.N., Ajah, H.A., 2020. Extraction of biosurfactant from Enterococcus spp. and effect on Candida spp. Plant Archives 20, 6453-6456.

412. Gharib, S.J., Abdullah, S.K., 2020. Onychomycosis Due to Fusarium oxysporum in Sulumaniyah City, Iraq. JCDR $14, \quad 1-3$. https://doi.org/10.7860/JCDR/2020/42846.13446

413. Hussain, M.A., Al-Hassan, M.S., Eslamic, H., Babylon, U., 2020. Evaluate propolis activity to inhibition of opportunistic fungi isolate from soil. Plant Archives 20, 938-940.

414. Hussain, N.S., 2020. Antimicrobial activity of bacteriocins extracted of some gram negative bacteria on Candida albicans (MSc Thesis). College of Medicine, University of Diyala, Iraq.

415. Jasim, A., Khudhur, D., Abdullah, H., Abbas, A., Abed Jawad, M., 2020. Biotyping of Candida albicans isolated from the student's mobile phones. Merit Research Journal of Medicine and Medical Sciences 8, 558-561. https://doi.org/10.5281/zenodo.4121712 
416. Khaleefa, R.H., Ahmed, L.T., Hameed, D.S., 2020. Oral and Dermal Candidiasis Among Infants in AlBattol Teaching Hospital. djm 19, 147-156.

417. Khudhair, Z.Y., 2020. Study the fatal microbial effect of Pyocyanin toward oral and dermatological Isolates of molecular detected Candida albicans (MSc Thesis). College of Science, University of Diyala, Iraq.

418. Mohammed, T. K. Jasim, A. A., Abdullah, H. N., Alabbas, A. S., Abbas, A. H., Jawad, M. A., 2020. Isolation of some pathogenic bacteria from students' makeup as a part of biosafety in the medical laboratories. Biochemical and Cellular Archives 20, 6199-6205.

419. Lafta, A., Ali, H., 2020. Biosynthesis of silver nanoparticles using light and dark of Cladosporium cladosporioides and antifungal activity against pathogenic fungi causing onychomycosis. Plant Archives 20, 4689-4696.

420. Majeed, M.R., Khairallah, D.H., 2020. Efficiency of plant active compounds as anti-adhesion factors for clinical Candida albicans isolates in vitro. Iraqi Journal of Science 61, 2215-2225.

421. Al Masaoodi, N. N. H., Mohammed, B. T., Al-Janabi, J. K. A., 2020. Occurrence, morphological, and molecular characteristics of Trichophyton erinacei in Iraq. Drug Invention Today 14, 889-896.

422. Mohammed, A., Hamoody, A.-H., Raheem, O., AlObaidy, O., 2020. Isolation and identification of fungi caused otomycosis in Samarra city and inhibitory of some virulence gene. Annals of Tropical Medicine and Public Health 23, 1-10. https://doi.org/10.36295/ASRO.2020.23101

423. Mohammed, S.M., Ali, I.A., 2020. Molecular study of two fungi Millerozyma farinosa and Candida orthopsilosis by PCR using ITS gene and phylogenetic structuring tree isolated from diabetic patient in Baghdad. Plant Archives 20, 2003-2009.

424. Mohammed, M. M., Kasim, A. A., 2020. Identification of some dermatophytes isolated by PCR technique in Misan Province/Iraq. Indian Journal of Public Health Research \& Development 11, 2039-2046. https://doi.org/10.37506/ijphrd.v11i2.3317

425. Naser, S. K., Abood, M.S., 2020. Isolation and diagnosis of some dermatophytes using nitrogen base tracking technique (Scquence). Indian Journal of Forensic Medicine \& Toxicology 14, 977-984. https://doi.org/10.37506/ijfmt.v14i2.3025

426. Obaid, A.J., Al-Janabi, J.K.A., Taj-Aldin, W.R., 2020. Bioactivities of anethole, astragalin and cryptochlorogenic acid extracted from anise oil and Moringa oleifera on the keratinase gene expression of Trichophyton rubrum. Journal of Pure and Applied Microbiology 14, 615-626.
427. Razooqi, M.A., Al-Shammary, A.H.A., 2020. Biodegradation of recalcitrant foodborne clones of Candida albicans by hurdling with pasteurization posted by peppermint processing ecosystem in Baghdad, Iraq. Plant Archives 20, 4869-4879.

428. Safar, A.A., Ghafoor, A.O., Dastan, D., 2020. Screening of chemical characterization, antifungal and cytotoxic activities of essential oil constituents of Tagetes erecta L. from Erbil, Kurdistan Region-Iraq. Pol. J. Environ. Stud. 29, 2317-2326. https://doi.org/10.15244/pjoes/110612

429. Salah, N.S., Muhsen, T.A.A., Risan, M.H., 2020. Antifungal activity of silver nanoparticles using Penicillium chrysogenum extract against the formation of biofilm for Candida glabrata. Indian Journal of Forensic Medicine \& Toxicology 14, 379-384. https://doi.org/10.37506/ijfmt.v14i2.2820

430. Shabaa, R.A.H., 2020a. Detection of Malassezia species isolated from Pityriasis versicolor infections in An Najaf, Iraq. Systematic Reviews in Pharmacy 11, 109-112. https://doi.org/10.31838/srp.2020.12.17

431. Shabaa, R.A.H., 2020b. Isolation, identification, and antifungal sensitivity testing of Epidermophyton floccosum from clinical samples. Systematic Reviews in Pharmacy 11, 70-77. https://doi.org/10.31838/srp.2020.12.12

432. Sharba, F.Y.J., Samaka, H.M., Majeed, A.H., 2020. Effect of Eruca sativa (Rocket salad) extract on the growth of Candida albicans in vitro. Plant Archives 20, 431-433.

433. Touhali, I., Mohammed, M.I., 2020. Isolation and molecular detection of dermatophytes from horses in the governorate of Wasit, Iraq. Annals of Tropical Medicine and Public Health 23, 147-154. https://doi.org/10.36295/asro.2020.23517

434. Yassin, N.A., Oumeri, N.M.Q., 2020. Identification of Fungi in burn wounds using conventional and Vitek system in Duhok City, Iraq. Science Journal of University of Zakho 8, 62-65. https://doi.org/10.25271/sjuoz.2020.8.2.701

435. Adeeb, M., Majead, R., Nazzal, M., 2021. Fungal study in patients with allergic bronchopulmonary in Baqubah city. Biochemical and Cellular Archives 21, 439-442.

436. Ahmood, A.A.J., 2021. Isolation of fungi from otitis media patients in Erbil city. Journal of Medical and Pharmaceutical Sciences 3, 48-62.

437. Al-Abedi, H., 2021. Aspergillosis in sheep. IOSR Journal of Agriculture and Veterinary Science 14, 4752. https://doi.org/10.9790/2380-1402024752

438. Al-Edani, A.J.M., Hussein, S.F., 2021. Evaluation of the activity of alcoholic extract of Frankinens (Boswellia spp.) against some dermatophytes and 
pathogenic Fungi of Plant Crops. Scientific Journal of Medical Research 5, 20-24.

439. Al-Ezzy, A.I., Abdulameer, S.J., 2021. Phenotypic identification and molecular characterization of Gliotoxin producing Aspergillus fumigatus isolated from hunters with special emphasis to clinical manifestations and risk factors In Diyala Province Iraq. Diyala Journal for Veterinary Sciences 1, 34-48.

440. Al-Garawyi, A.M.A., Al-Hamadani, A.H., Bederi, A. Waheed A.-, 2021a. Prevalence and incidence of dermatophytosis in Al-Diwaniya City, Iraq. Indian Journal of Forensic Medicine \& Toxicology 15, 18131817. https://doi.org/10.37506/ijfmt.v15i2.14602

441. Al-garawyi, A.M.A., Al-Hamadani, A.H., Bederi, A. waheed A.-, 2021b. Detection of fungal toxins Produced by dermatophytes by using thin layer chromatography. Indian Journal of Forensic Medicine \& Toxicology 15, 2434-2438.

442. Alhilal, M., Sulaiman, Y.A.M., Alhilal, S., Gomha, S.M., Ouf, S.A., 2021. Antifungal activity of new diterpenoid alkaloids isolated by different chromatographic methods from Delphinium peregrinum L. var. eriocarpum Boiss. Molecules 26, 1375. https://doi.org/10.3390/molecules26051375

443. Al-Janabi, A.A.H.S., Al-Khikani, F.H.O., 2021. Prophylaxis and therapeutic ability of inactivated dermatophytic vaccine against dermatophytosis in the Rabbits as an Animal Model. tjps 18, 326-331.

444. Al-Mahmood, A., Al-Sharifi, E., 2021. Epidemiological characteristics and risk factors of tinea pedis disease among adults attending Tikrit Teaching Hospital/ Iraq. Infect Disord Drug Targets 21, 384388.9

445. Al-Nasrawi, H., 2021. Cutaneous mycoses among Diabetes patients. Annals of the Romanian Society for Cell Biology 25, 10949-10956.

446. AL-Yasiri, K.S., Hamed, N.S., 2021. Study the effect of Oreganum vulgare L. extract against some pathogenic fungi. Annals of the Romanian Society for Cell Biology 25, 9243-9252.

447. ElGindi, M., Al-Baghdadi, R., Jackman, A.B., Antonyan, A.S., McMahon, D.L., Taj-Aldeen, S.J., Finkel, J.S., 2021. Where the infection is isolated rather than the specific species correlates with adherence strength, whereas biofilm density remains static in clinically isolated Candida and arthroconidial yeasts. Can. J. Microbiol. 67, 497-505.

448. Farhan, R.K., 2021. Dermatophytes and bacterial super infections in antimicrobial resistant tinea pedis patients in Dour city, Iraq. European Journal of Molecular \& Clinical Medicine 8, 1396-1408.
449. Farid, H.A., Hashim, A.R., Hasrat, N.H., 2021. Rhinocerebral mucormycosis as a COVID-19-related complication: A case report from Basra city, Southern Iraq. Journal of Global Scientific Research 6, 1369 1374.

450. Hussein, H.M., Sekhi, A.A., Sekeb, H.S., 2021. Prevalence of fungi in clinically suspected cases of pulmonary tuberculosis In Iraq, Wasit. Systematic Reviews in Pharmacy 12, 1393-1396. https://doi.org/10.31838/srp.2021.1.198

451. Jameel, N.R., Abdulla, A.B.A.S., Abd, H.A., 2021. Isolation and identification of the fungi that causes eye infection in Wasit Province, Iraq. Annals of the Romanian Society for Cell Biology 25, 10209-10217.

452. Kakamad, F.H., Mahmood, S.O., Rahim, H.M., Abdulla, B.A., Abdullah, H.O., Othman, S., Mohammed, S.H., Kakamad, S.H., Mustafa, S.M., Salih, A.M., 2021. Post covid-19 invasive pulmonary Aspergillosis: A case report. International Journal of Surgery Case Reports 82, 105865.

453. Khalaf, H.Y., Awadh, H.A., Younis, H.M., Jasim, N.A., Abass, K.S., 2021. The effect of antifungal and Ago and Zno nanoparticles on Trichophyton mentagrophytes. Pakistan Journal of Medical and Health Sciences 15, 1026-1029.

454. Nabok, A., Al-Jawdah, A.M., Gémes, B., Takács, E., Székács, A., 2021. An optical planar waveguide-based immunosensors for determination of Fusarium mycotoxin zearalenone. Toxins 13, 89. https://doi.org/10.3390/toxins13020089

455. Omran, T.Z., Mahdi, M.A., Mashallah, N.H., ALAraji, A.E., 2021. Association between the effect of blood estrogen level and breast cancer on vaginal fungal infection. Latin American Journal of Pharmacy 40, 240-247.

\section{Competing interests}

The authors declare that they have no conflict of interest.

\section{Dedication}

The authors dedicated this work to a strong and pure soul of Perixan Ali Shilazi, who passed away during preparation of this work, and she was one of the strong souls that bravely battled liver cancer for three years. Also, we dedicated this work to the Iraqi Mycologists' Network (http://fungiofegypt.com/Network/Iraq/index.html) which founded in 2021 by the last author to gather all Iraqi mycologists under such umbrella. 